\title{
Fertility of Roma Minorities in Central and Eastern Europe
}

\author{
Laura Szabó, Igor Kiss, Branislav Šprocha, Zsolt Spéder
}

\begin{abstract}
We analyse Roma fertility in four neighbouring countries in Central and Eastern Europe with a large Roma minority: in Hungary, Slovakia, Romania and Serbia. The sources of data are the respective national population censuses from 2011. Fertility is measured at the birth cohort level as the average number of children ever born. We make an international comparison of the fertility of Roma and nonRoma majority population women on the basis of completed education. In the case of Hungary, we also explore how the correlation between fertility and ethnic identity is modified when completed education and ethnic residential segregation are controlled.

The fertility of Roma women is far above the majority population average in all birth cohorts and in each country. Educational attainment modifies this relationship. The fertility of highly educated Roma and majority population women is converging. The exposure to majority behaviour also has an effect. The lower the level of ethnic residential segregation, the smaller the difference between the fertility of Roma and majority population women. Completed education and residential segregation may exert different forces at the two ends of the educational hierarchy when their joint effect is explored. At the upper end of the social hierarchy, neither segregation nor ethnicity matters; at the lower end, however, both exposure to ethnic majority behaviour and ethnicity matter.
\end{abstract}

Keywords: Roma $\cdot$ Fertility $\cdot$ Education $\cdot$ Residential segregation

\section{Introduction}

The total fertility rate of Central and Eastern European (CEE) countries is below the replacement level (Eurostat 2018). However, there are some demographic groups within these countries with fertility rates around or above the replacement level, such as the Roma population. Previous analyses from the 1990s (Haug et al. 1998, 2000) which measured the fertility of the minorities in European countries highlighted the high fertility of the Roma population in CEE countries (Kalibova 2000). One of our own previous calculations from the 2010 s indicated that, while the cohort fertility of 
different national minorities living in Hungary, Slovakia, Romania and Serbia did not differ significantly from that of their respective majority populations, that of Roma women ${ }^{1}$ did (Szabó et al. 2017). There is broad consensus among professionals from CCE countries about the higher fertility of the Roma minority population, at least as compared to the majority population (Kemény/Janky 2003; Hablicsek 2007; Vaňo 2002; Śprocha 2017). However, the figures describing the fertility of Roma women are often merely estimates (Hablicsek 2007; Vaňo 2002).

These estimates are frequently criticised, either due to limitations regarding the identification of the Roma population ("who is Roma?", Kalibova 2000; Durst 2006; Ladányi/Szelényi 2001) or because of over-generalization of the results of small-scale anthropological or ethnographic studies carried out in geographically delimited areas. Moreover, some of them are inaccessible to an international audience, since papers are often written in less widely understood national languages (Havas et al. 1998; Berevoescu et al. 2002; Zamfir/Preda 2002; Kemény/Janky 2003; Hablicsek 2007; Husz 2011; Šprocha 2017; Šprocha/Ďurček 2017; Obádovics et al. 2019).

Our work is based on the assumption that population census data are one of the most suitable sources for analysing fertility by ethnicity across Central and Eastern Europe (CEE). Our paper contributes to the existing literature by 1) publishing more recent figures on Roma fertility in a comparative manner from four countries of CEE with a large Roma minority, from which the relevant statistics were available: Hungary, Romania, Serbia and Slovakia, 2) using broader population data (quasi full censuses), and 3) exploring the Roma / non-Roma fertility gap by birth cohort, level of education and level of ethnic residential segregation.

Comparing Roma and non-Roma fertility within their different subgroups is an interesting endeavour, as Roma have been settled in CEE countries for a century in a relatively homogenous economic and social environment, yet still have higher fertility rates than those of the majority societies. Thus, the question arises as to the reasons behind this fertility gap between the Roma minority and non-Roma majority population.

While it is common in fertility research to interpret the development of fertility in international comparison (as this allows for better exploration of general and specific trends), this is not the case regarding the Roma population. To our best knowledge, only Kalibova (2000) has compared the fertility of Roma women living in CEE coutries as well as other Balkan countries to date, but she also only looked at the period of 1991-1994 (i.e., not based on the latest census data, as our study is), and did not compare different socio-demographic subgroups of Roma women. Previous research has established (for an overview, see Balbo et al. 2013), that fertility is differentiated by a number of factors, one of them being the educational level of women (Jalovaara et al. 2019). As ethnicity is also a determining factor (Kulu et al. 2019), the question arises as to whether a social determinant such as

1 The 2011 population census from Hungary, Slovakia, Serbia and Romania classifies the Roma either as a national or an ethnic minority. We use both terms throughout the paper. Although practically all members of the Roma people call themselves Gypsies, at least in Hungary, in this paper, we use the more politically correct terminology of "Roma". 
education level influences the fertility of the ethnic majority and the Roma minority to the same degree.

According to previous research, childbearing is driven not only by structural factors, but also by the subculture of the different groups (Forste/Tienda 1996; Durst 2011; Kulu et al. 2019). Therefore, in this paper, we explore how the relationship between fertility and ethnicity varies at different levels of ethnic residential segregation within neighbourhoods in the case of Hungary. The level of segregation is used as a proxy for subcultural influences. Moreover, the results of the joint examination of completed education and ethnic residential segregation may contribute to the discussion on the role of "structure" and "culture" in the fertility of Roma minority populations. ${ }^{2}$

Our results confirmed that the distinct fertility pattern of Roma - namely, early and high fertility - is very similar in the four selected countries. On the other hand, they also highlighted how certain groups among the Roma women have different fertility patterns. The higher the educational attainment of Roma women, the lower their fertility. And the less segregated they live, the lower their fertility. In addition, the fertility gap between the Roma and the majority population from the selected countries narrows as the level of education increases. Joint examination of the level of education and ethnic residential segregation in Hungary, however, indicated a divergence in cohort fertility only between Roma women with a medium level of education and non-Roma majority population women with a medium level of education, as the level of residential segregation increased. Thus, we concluded that these two factors may exert different forces at the two ends of the educational hierarchy. Among highly-educated Roma and non-Roma women, there is no fertility gap at any level of segregation, while less-educated non-Roma women exhibit increasingly minority-like high fertility when living in neighbourhoods with a high proportion of Roma.

We proceed as follows in the paper. The second section provides an overview of theoretical assumptions about majority-minority fertility differences. We present a short overview of the situation of Roma in CEE countries in section three, followed by a description of previous study results on Roma fertility. Section four introduces the data and methodology and presents the measures and indexes we use in our analyses. Section five contains the results: the cohort fertility differences by ethnicity, educational level and country; and, in Hungary, by ethnicity, educational

2 However, see the opinion of Small et al. (2010: 3): "[The new generation of scholars] is often reluctant to divide explanations into "structural" and "cultural," because of the increasingly questionable utility of this old distinction. [...] Part of the problem is that, in sociology, the term "structure" has been defined in several different ways. [...] When applying the structure-culture distinction in its simplest and most straightforward form, scholars argue that the behaviour of the poor results not from their values (culture) but from their lack of financial resources (structure), whether this deprivation is individual (as in the case of material hardship) or collective (as in the case of under-funded schools or organizationally isolated neighbourhoods)." Small et al. (2010: 3 ) argue that "ideas such as "ethnic cultures" or "ghetto culture" lack much explanatory power." However, they agree that "the substantial variation in responses to similar financial constraints (whether individual or collective constraints) makes clear that such material constraints cannot explain everything." 
level and ethnic residential segregation level. We discuss our results in section six, and end the paper with the conclusion in section seven, including notes on our contribution, and limitations of the study.

\section{Theoretical approaches to the fertility of minorities}

The assumptions regarding the differences in the fertility of majority and minority populations basically follow three directions of thinking. These theoretical perspectives are not mutually exclusive, however.

\section{Social characteristics assumption}

The earlier research on minorities' fertility focused on differences between groups based on social characteristics. This avenue of thinking has a long tradition in the United States, as the fertility of people belonging to different ethnic groups and minorities (Black, Irish, American Japanese, Jewish) has been distinct from that of the majority population for a long time (Goldscheider/Uhlenberg 1969; S/y 1970; Kennedy 1973). In this approach, researchers assume that differences in fertility of majority and minority populations depend on the social characteristics of individuals, such as educational or income level. If all groups had the same social characteristics, there would be no differences in their fertility. This assumption adopts the perspective of modernization/long-term assimilation: a minority will converge with the majority population, but the pace of convergence depends on the social characteristics of given minority members (Dubuc 2017; Martin 2020; Kulu et al. 2019). Highly educated people will be the first to adapt their fertility to that of the majority behaviour (Johnson 1979). However, Johnson (1979) has made a noticeable distinction between the "strong form" and "weak form" of the characteristics hypothesis when analysing the differences in black and white populations' fertility in the USA in the 1970s. In his view (1979: 1388), the "weak form" of the characteristics hypothesis predicts that in the initial stage of sociodemographic transition, there would be higher black than white fertility among the less well educated, with no racially based difference among the highly educated. The "strong form" of the characteristics hypothesis predicts no black-white differences at any educational attainment level. Here, we should note that empirical studies yielded rather contradictory results regarding the social characteristics hypothesis (Anderson et al. 2018; Shain 2019; Wilson 2019, 2020; Šprocha/Tišliar 2019).

\section{Minority group status assumption}

When Goldscheider/Uhlenberg (1969) analysed the 1960 US census data, they found that educated (non-white) minorities had lower fertility than educated majority women, based on which they formulated the so-called minority group status hypothesis. This states that belonging to a minority has its own effect on fertility - either in a positive or in a negative way, depending on the perceived possibilities of upward social mobility. Members of a minority group experience discrimination, marginality and greater barriers to social mobility; accordingly, the 
prerequisite for them to acquire higher social status or successful mobility is the investment of resources, and holding back their fertility (Kulu et al. 2019; Wilson 2019, 2020; Martin 2020). However, in circumstances of deprivation and territorial, educational and occupational segregation, where there is very limited scope for mobility among minority people, fertility may be high; this is because minorities may expect that having children will improve their social and economic prospects, or will provide insurance against potential discrimination (see the "critical mass" argument Goldscheider 2006; or the "weapon of womb" argument Bezin et al. 2018; Chabé-Ferret/Ghidi 2013).

These lines of argument are in accordance with Johnson's distinction (1979: 1389), who also distinguished the minority-status hypothesis of "strong" and "weak" forms. According to him, the "strong form" of this hypothesis predicts differences between blacks and whites at every level of education: higher black than white fertility in case of the lower educated, and lower black than white fertility among the highly educated. The "weak form" of the minority-status hypothesis states that there is no difference between groups in terms of fertility at lower levels of education, but we can see lower black than white fertility at higher levels of education.

\section{Subcultural assumption}

The minority position itself may also influence fertility through effects of the minority-majority relationship. Social mixing, and encountering different cultural and social norms seems conducive to rapid behavioural change as well (Battaglia et al. 2021; Gamella 2018). The cultural and psychological change that takes place as the result of contact between different groups and their individual members may also be related to the process of acculturation (Schwartz et al. 2010). Although socio-economic characteristics may explain a certain variance in fertility among majority and minority populations, significant differences remain after controlling for them (Andorka 1987; Kulu et al. 2019; Wilson 2019, 2020; Forste/Tienda 1996; Wilson/Kuha 2018; Šprocha/Tišliar 2019).

The cultural explanations suggest that behavioural differences between majority and minority populations not only rest on socio-economic characteristics, but also derive from diverging values, norms, habits, frames or repertoires, favouring particular family-formation and reproductive patterns. Individuals' behaviour is influenced by the normative environment of their proximate neighbourhood or community. Following the arguments of Wilson/Kuha (2018) we can measure the degree of exposure to this normative environment by measuring the (ethnic) composition of these neighbourhoods. Thus, the ethnic composition of a residential location can be seen as a measure of the exposure of individuals to the cultural norms of their community (Forste/Tienda 1996; Wilson/Kuha 2018). On the other hand, however, "culture" (that could be measured in different ways, see Small et al. 2010) may also exert an influence on fertility via proximate determinants of fertility through sexual behaviour, contraceptive use, partnership formation, marital patterns. Wilson/Kuha (2018), testing the childhood socialization hypothesis, demonstrate, for example, that migrants who come to a country as children and 
are exposed to the cultural norms of the host society early on are less likely to have completed fertility that differs significantly from that of the native-born population.

At the end of the theoretical overview, we should stress that our analysis is not able to statistically test the three concepts mentioned above, since the census data only cover a limited number of factors. Moreover, cross-sectional data are very limited in their ability to reveal causal relations. However, the two factors we trace beyond ethnicity - level of education and degree of ethnic residential segregation - are powerful elements in understanding fertility. The level of education is a key socio-economic characteristic that strongly determines labour market success and material well-being (although, here, we should note the endogeneity problem between education and fertility). The share of Roma within a neighbourhood could provide an accurate reflection of the exposure to a normative environment, and therefore act as a proxy for subcultural contextual influences. All in all, our findings on the joint impact of these two factors and our comparison of the four countries may provide partial evidence for and against the approaches presented above.

\section{Review of Roma fertility: summary of previous results}

\subsection{Roma population in CEE countries}

The Roma are Europe's largest minority, with an estimated 10-12 million people (European Union Agency for Fundamental Rights - FRA/UNDP 2012). Some of the groups of Roma settled in CEE countries more than 600 years ago. However, they only started to be recognised as ethnic or national minorities by governments (in CEE countries) after the fall of communism in most cases. Under socialist and communist dictatorships, governments made no effort to enforce human, minority or child rights considerations regarding the Roma. Around that time, the goal of the governments was to eliminate the Roma as nationalities and as groups with distinct ways of life, which led to their forced settlement, employment and education.

However, after the regime change in the 1990s, European Union (EU) institutions, the United Nations International Children's Emergency Fund (UNICEF) and the United Nations Development Programme (UNDP), as well as international human rights foundations (Open Society Foundation, European Roma Rights Centre, Roma Education Fund) tried to introduce hitherto untried schemes in this area. Roma integration was explicitly included in the Europe 2020 growth strategy framework and there is now evidently political commitment from EU Member States to improve the situation of Roma (European Commission - EC 2011). In order to fulfil these expectations, robust data and valuable evidence were needed by the EC (in addition to national population censuses). Therefore, a joint research project was initiated by the FRA, the UNDP, the World Bank and the European Commission in 2011, called the Roma Survey. The survey report came to the following conclusion: "Roma [...] are victims of racism, discrimination and social exclusion. Of those surveyed in this report, one in three is unemployed, 20 percent are not covered by health insurance, and 90 percent are living below the poverty [line]. Many face prejudice, intolerance, 
discrimination and social exclusion in their daily lives. They are marginalised and mostly live in extremely poor socio-economic conditions" (FRA/UNDP 2012: 5). ${ }^{3}$ These facts characterise the situation of Roma in the four selected countries in our analyses, too (FRA/UNDP 2012; FRA/UNDP 2018). Majorities in most countries would not be willing to accept Roma in their family: this was the view of 65 percent in Romania, 54 percent in Hungary, and 49 percent in Serbia in 2016 (Pew Research Center 2017).

In terms of their demographic composition, CEE countries' populations are characterised by an increasing proportion of elderly people and a decline in the number of children, while the Roma communities are characterised by a high proportion of children and a low proportion of elderly people. These trends can be detected in Hungary, Romania, Slovakia and Serbia (Table 1). The most striking fact, however, is that the overwhelming majority of the Roma population is less

Tab. 1: $\quad$ The sex and age structures of the Roma and majority populations

\begin{tabular}{|c|c|c|c|c|c|c|c|c|c|c|}
\hline & \multicolumn{2}{|c|}{$0-14$ years old } & \multicolumn{2}{|c|}{$15-49$ years old } & \multicolumn{2}{|c|}{$50-64$ years old } & \multicolumn{2}{|c|}{$65+$ years old } & \multicolumn{2}{|c|}{ Total } \\
\hline & Male & Female & Male & $\begin{array}{r}\text { Female } \\
\text { in }\end{array}$ & $\begin{array}{l}\text { Male } \\
\%\end{array}$ & Female & Male & Female & $\begin{array}{c}\text { Male } \\
(100 \%)\end{array}$ & $\begin{array}{l}\text { Female } \\
(100 \%)\end{array}$ \\
\hline \multicolumn{11}{|c|}{ Majority population } \\
\hline Hungary & 15.3 & 13.0 & 49.6 & 43.6 & 21.1 & 21.9 & 14.0 & 21.6 & $3,875,571$ & $4,352,728$ \\
\hline Romania & 15.3 & 13.7 & 50.2 & 45.4 & 20.4 & 21.3 & 14.1 & 19.6 & $8,172,326$ & $8,620,542$ \\
\hline Slovakia & 15.7 & 14.0 & 54.5 & 49.9 & 19.9 & 20.7 & 9.9 & 15.4 & $2,102,887$ & $2,249,888$ \\
\hline Serbia & 14.4 & 13.0 & 47.2 & 43.9 & 23.0 & 23.3 & 15.4 & 19.7 & $2,918,647$ & $3,069,503$ \\
\hline \multicolumn{11}{|c|}{ Roma population } \\
\hline Hungary & 33.3 & 32.2 & 54.6 & 54.4 & 10.2 & 10.4 & 1.9 & 2.9 & 156,094 & 152,863 \\
\hline Romania & 33.9 & 33.3 & 53.1 & 51.2 & 10.0 & 10.8 & 3.0 & 4.7 & 316,055 & 305,518 \\
\hline Slovakia & 39.7 & 39.1 & 50.2 & 49.6 & 8.4 & 8.7 & 1.7 & 2.5 & 53,721 & 52,017 \\
\hline Serbia & 32.2 & 32.1 & 51.2 & 50.0 & 13.1 & 13.4 & 3.4 & 4.6 & 75,042 & 72,562 \\
\hline
\end{tabular}

Full population data. Observations: Slovakia - data regarding the age of 677 Slovak people and 38 Roma people are missing. Hungary: Roma are those who choose to state Roma as their first or second nationality.

Source: national population censuses 2011, from Hungary, Romania, Slovakia and Serbia.

3 The survey covered 11 European Union countries and six non-EU countries from the Western Balkans and Moldova. However, we should keep in mind that the FRA/UNDP/World Bank/EC 2011 Roma Survey results are representative only of Roma living in areas with a higher-thannational average density, i.e., of Roma who are more at risk of exclusion. Thus, the results are not representative of the entire Roma population living in the target countries. However, they provide sufficiently robust data to set the targets for Roma integration (FRA/UNDP 2012). 
well-educated (see also Appendix Tab. A1), while the share of the highly educated is merely around 1 percent.

\subsection{Roma fertility compared to that of society as a whole}

Estimates of Roma fertility in CEE countries are based either on census or on survey data. To our knowledge, only Kalibova (2000) provided comparative evidence of differences in Roma fertility in Bulgaria, Czech Republic, Hungary, Romania, Slovakia, Slovenia and the former Yugoslav Republic of Macedonia, using national censuses from 1990 to 1994. She found that Roma fertility was approximately double that of the overall population in the period studied.

Besides this comparative analysis there are several individual country-results regarding Roma fertility. According to large-scale survey research led by István Kemény in 1971, 1993 and 2003 in Hungary, the total fertility rate (TFR) of the Roma was around 3.0 in 1999-2002, while Hungary's overall TFR was 1.3. (However, the Roma population was identified not by self-declaration but by the neighbourhood community in these surveys Kemény/Janky 2003). Using census data, Hablicsek (2007: 12) estimated an average number of 2.91 children for Roma for the year 2001 in Hungary. Durst (2006) conducted a small-scale anthropological case study in a Roma-majority village in Hungary in 2000-2004 and found that the crude fertility rate of Roma was $34.8 \%$, three and a half times that of the total population $(9.7 \%$; Durst 2006: 54).

The Roma and non-Roma differences in fertility were not only documented in Hungary, but also in the neighbouring countries. Šprocha (2017), based on 2011 census data, found that the cohort fertility of Roma women born in the second half of the 1960s is around 3.5, while among non-Roma it is 2.1 in Slovakia. Sobotka et al. (2008) analysing the UNDP/ILO 2001 survey data shows that, in most age categories, the mean number of children born to Roma women in the Czech Republic exceeds that of the number of children born to all women by a factor of 2 or more; Roma women born before 1952 had 5.3 children on average, compared to 2.1 of the total population. For Bulgaria, Koytcheva/Philipov (2008) estimated from the 2001 census data that the TFR for the year 2000 was 1.1 for the Bulgarian ethnic majority and 3.0 for Roma women.

\subsection{Fertility differences within the Roma population}

Studies devoted to understanding the population dynamics of the Roma minority highlight differences within the community. These differences are either due to social-geographic factors (such as type of settlement or degree of segregation) or to structural features.

\section{Social-geographic differences and segregation}

Representative studies in Hungary find territorial differences within the Roma population. A survey in Hungary from 2001, comparing territories with aboveaverage Roma population from the northeast and southwest parts of the country, 


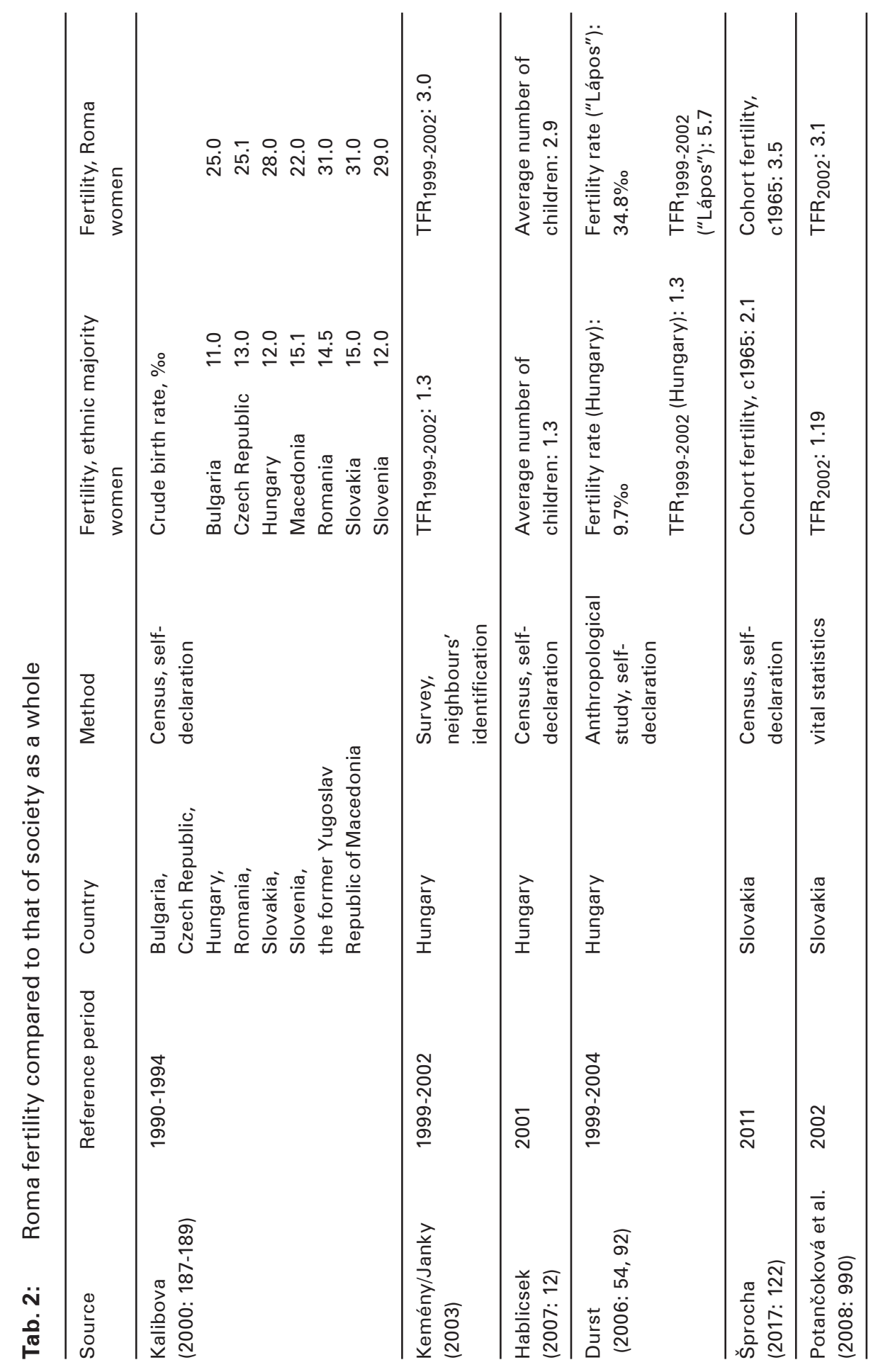




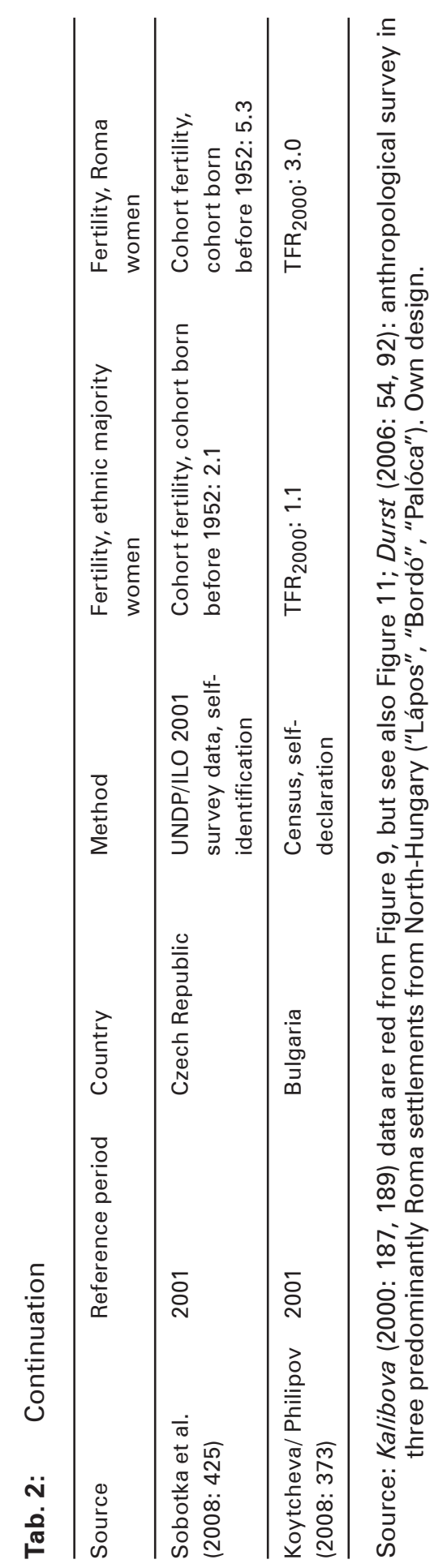


found a TFR of 2.6 and 2.1, respectively (Husz 2011: 13). Another small-scale Hungarian ethnographic study, focusing on two neighbouring settlements, stresses the importance of segregation: whereas in a predominantly Roma settlement ("Lápos"), the fertility among segregated Roma women born in 1951-1969 was 5.8, among the "assimilated" Roma women of the same age it was 2.9 (Durst 2006: 85); and in a neighbouring settlement ("Bordó") where Roma had been well-integrated for decades, fertility was clearly lower: 3.00 (Durst 2006: 171).

Similar territorial differences from neighbouring countries have been reported by others too. They found significant differences in cohort fertility among Roma women living in urban and rural areas in Slovakia, as well as in smaller and larger municipalities (Šprocha/Ďurček 2017: 111). The fertility of the Roma population differs based on the level of integration, too. In 2002, the overall TFR in the Slovak Republic was 1.19, while it was 3.1 for the total Roma population; but the TFR of integrated Roma was 1.3, 3.0 for the partially integrated Roma, and 4.6 for segregated Roma (Potančoková et al. 2008: 990). Fertility also depends on the concentration of Roma in a given neighbourhood. Battaglia et al. (2021: 244) found that in neighbourhoods with a small number of Roma, there are 2.7 children per household; in neighbourhoods that consist of mostly Roma, the figure is 3.2 ; while in totally Roma-populated neighbourhoods it is 3.6.

\section{Structural factors}

Explanations of the relationship between fertility and level of segregation often point to factors such as low economic activity, high non-employment and below-average education of women. Durst's (2006: 32) research in Hungary demonstrated that the fertility difference between Roma and non-Roma women depends largely on whether or not they have completed primary education (i.e., eight classes of schooling). If they have not, the mean number of children is 3.66 for Roma and 2.65 for non-Roma women. Considering those who have completed at least primary education, both Roma and non-Roma have the same average number of children (2.21). According to our earlier calculation, Roma women with lower levels of education (completed primary schooling or less) had a TFR of 2.79 in 2010, those with vocational education or above had a TFR of 1.79, which is below the replacement level (Obádovics et al. 2019). The corresponding TFR figures for all women living in Hungary were 1.81 and 1.21, respectively (Obádovics et al. 2019).

Although a case study by Preda (2010) of southern Romania reports on territorial inequalities within the Roma population, the description of the communities is based on the structural position (dominant occupation) of the Roma. She found communities from southern Romania - from the woodworker, brick-maker and beartamer clans - to have very high fertility rates (more than four children per family). All these clans were very poor, had low levels of education, were living off social welfare, and had bleak future prospects. There were other Roma communities with a moderate fertility rate (2-3 children per family) - including members of the coppersmith, woodworker, bear-tamer, brick-maker and silversmith clans who lived in an urban environment, had slightly higher levels of education than 


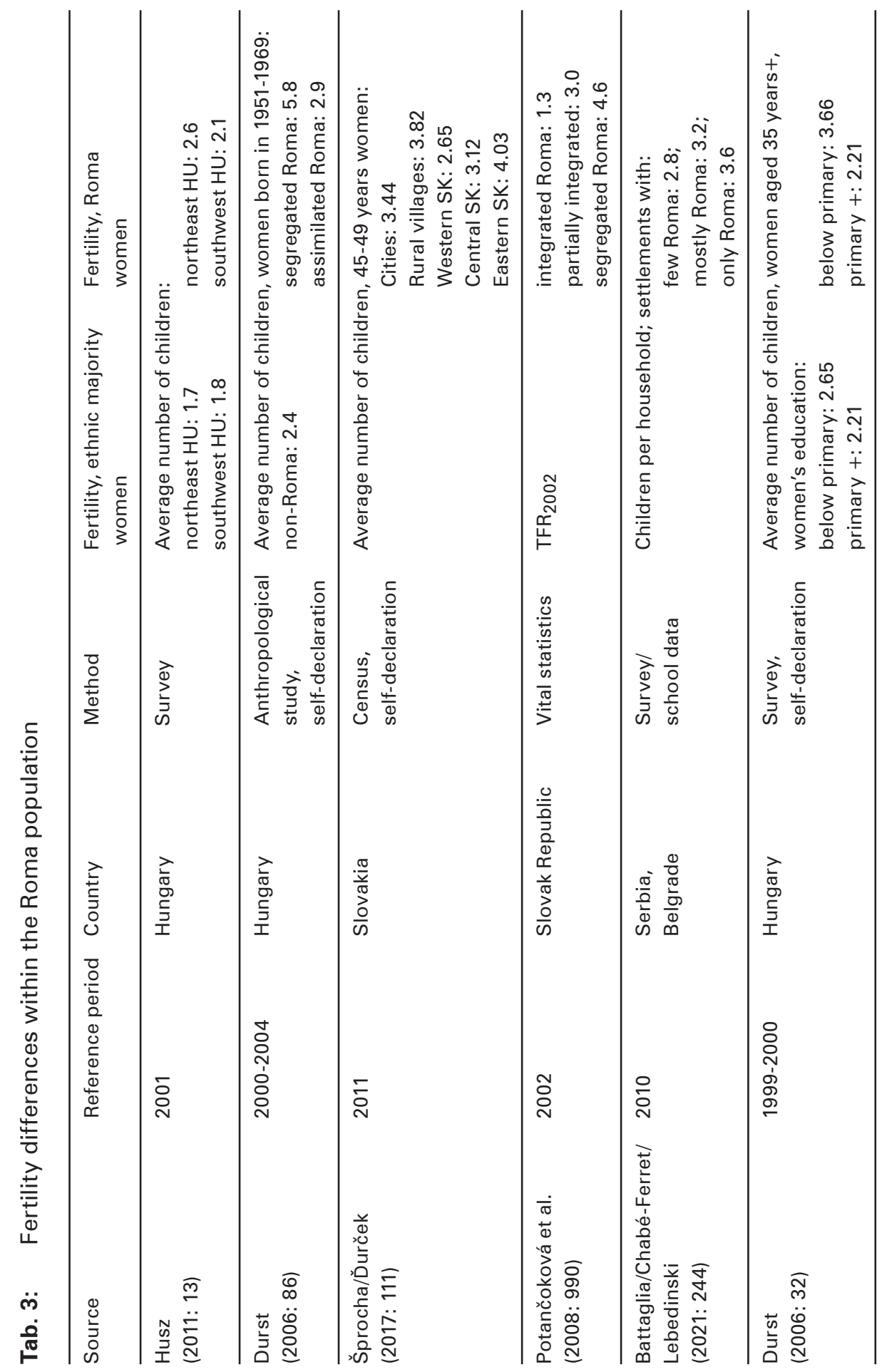




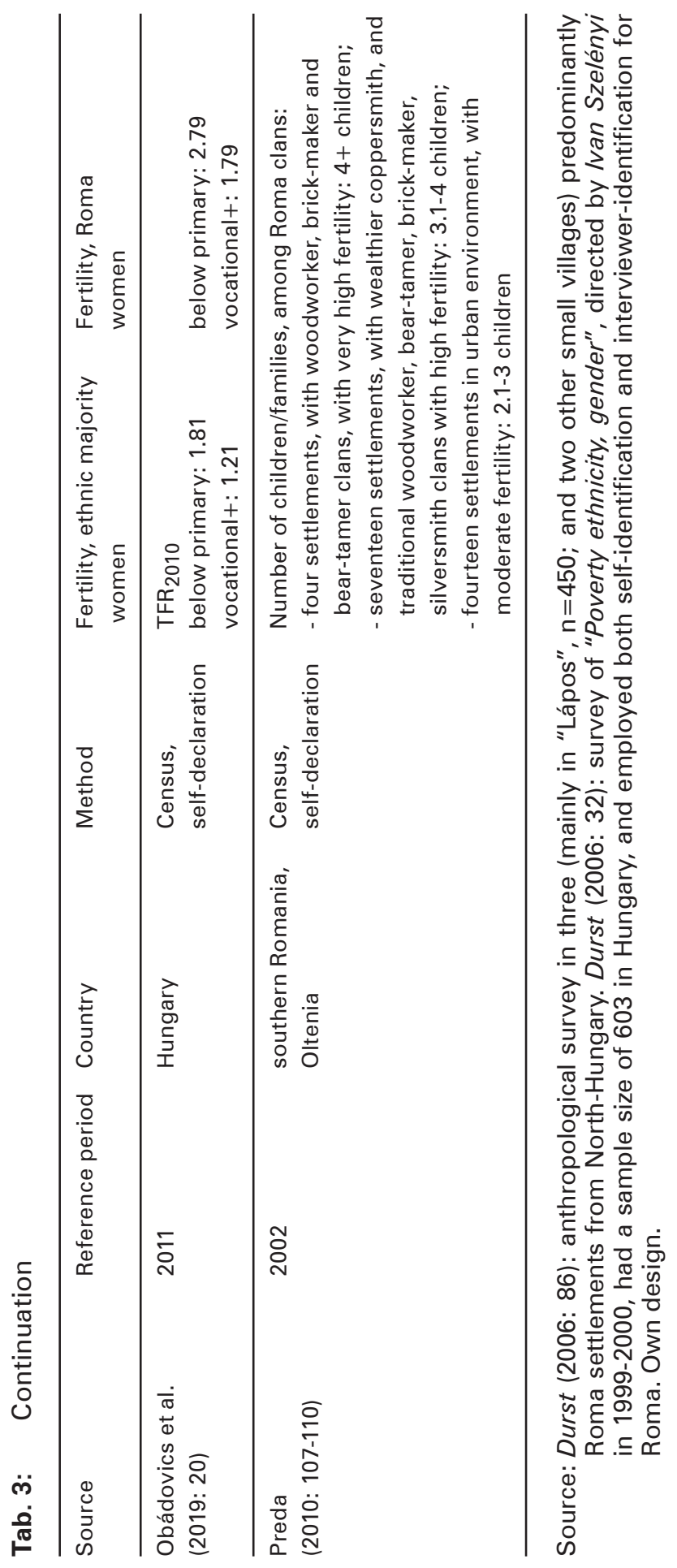


their counterparts in rural areas, and who had a number of income-generating opportunities available to them due to their residence in an urban setting.

\section{$4 \quad$ Data and methods}

\section{Census data}

Our analysis is based on national population census data from four selected countries, from 2011: Hungary, Slovakia, Romania and Serbia (Appendix Tab. A1). The individual-level database was available for us in the case of Hungary, while we acquired tabulated data by women's nationality, birth cohort and completed education in the case of Slovakia, Romania and Serbia. In three countries - Hungary, Slovakia and Serbia - calculations were based on the full population data; In the case of Romania, calculations were based on the 10 percent IPUMS sample (IPUMS 2018). As far as we can assess, the Romanian IPUMS sample is representative in terms of cohort, ethnicity and education. ${ }^{4}$ Shortcomings of the census data are not discussed here (see Kalibova 2000; Durst 2011; Kushen 2015), however, we should note that 8.6 percent of women aged 30-59 in Slovakia did not answer the question on their number of children, rising to 12.1 percent for Roma women of the same age (Appendix Tab. A5).

\section{Identifying the Roma: theoretical approaches and technical problems}

Two ways of defining the Roma population exist in the literature. Some approaches are based on declared identity (self-identification); others rely on outsiders' identification (external classification). ${ }^{5}$ The 2011 national population censuses from Hungary, Slovakia, Romania and Serbia applied the self-identification method. We should mention here that the number of self-identified ethnic Roma is always around two or three times lower than the number estimated by experts (Nestorová Dická 2021; Pénzes et al. 2018; Kemény/Janky 2003). But whereas the citizens had to identify a single nationality/ethnicity for themselves in Slovakia, Romania and Serbia, they were able to choose a second one as well in Hungary (Appendix Tab. A2).

4 IPUMS-International data from Romania, 2011 is a systematic unweighted sample with no geographic clustering, but household clustering. For such samples, there is limited potential for underestimated variance which might lead to invalid statistical inferences. The only concern in these instances is clustering by household, but our research focuses on a particular subpopulation (women aged 30-59) that rarely cluster within households, as households typically have one such woman (IPUMS 2019a/b).

5 Without going into too much detail, we should note that in Hungary, around the turn of the millennium, there was fierce debate over questions such as who qualifies as Roma, how to identify Roma people, and whether ethnic or national categories may be defined objectively on the basis of origin (Durst 2011; Ladányi/Szelényi 2001; Havas et al. 1998). The self-declared nationality definition is distorted by the fact that the identification not only depends on the respondent's identity, but also on the historical and political context and on perceived discrimination. Furthermore, contextual factors are also present when an interviewer identifies someone as Roma, while other circumstances distort the identification of Roma when "labelled" by outsiders. 
However, we only use the primary identification for Hungary when we compare the data from all four countries. The countries also used different data collection techniques when inquiring about nationality/ethnicity: whereas in Slovakia it was compulsory, in Hungary, Romania and Serbia it was not. The figures for missing data on the nationality/ ethnicity questions are 3.5 percent in Serbia, 6.2 percent in Romania, 7.1 percent in Slovakia and 14.7 percent in Hungary (Appendix Tab. A1).

\section{Fertility measures}

We analyse the average number of children ever born to women within specific birth cohorts. This information is based on information provided by women.

\section{Birth cohort and age}

To overcome selectivity, based on the low life expectancy of the Roma population (Obádovics et al. 2019: 30) we limit our analysis to women born between 1952 and 1981 (i.e. aged 30-59 in 2011). In line with the usual age categories, we grouped the women into six birth cohorts: 1952-1956; 1957-1961; 1962-1966; 1967-1971; 1972 1976; 1977-1981. Women born between 1952 and 1971 have (almost) completed fertility, since it is rare to give birth above the age of 40 (Frejka/Sardon 2003). The two youngest birth cohorts of women born between 1972 and 1981, aged 30-39, are far from having completed fertility. However, it is worth including them in our analysis, as it makes it possible to detect differences between Roma and non-Roma fertility within the youngest cohorts.

\section{Level of education}

The completed education of women was measured at the time of the census. Three main groups were distinguished: "primary", corresponding to lower secondary education or less (ISCED 1997, 0-2); "secondary", corresponding to higher secondary and post-secondary non-tertiary education (ISCED 1997, 3-4); and "tertiary" university/college education (ISCED 1997, 5-6). The educational attainment of women is considered to be an exogenous variable in this analysis and is used as an indicator measuring the socio-economic position of respondents.

\section{Residential segregation - exposure to majority context}

The Hungarian census data contains several sub-settlement-level territorial variables. These are the geographical grid, the census (residential) blocks, city- or settlement districts, and voting districts. The census (residential) blocks are built-up areas enclosed by streets or natural boundaries. These territorial units were the smallest territorial building blocks of the 2011 census. ${ }^{6}$ The share of the Roma population is measured within these smallest territorial units, and thus can be considered as the share of Roma people within their proximate neighbourhood. This index is grouped

6 HCSO (downloaded at 12.03.2021): Regional Atlas - Below-settlement-level statistics. http:// www.ksh.hu/regionalatlas_other_territorial_delimitations?lang=en 
into four categories: residential blocks with a Roma proportion between 0 and 5 percent; $5-20$ percent; $20-40$ percent, and more than 40 percent.

We use this measure of segregation, as the census residential blocks cover neighbourhoods of those who reside in close proximity to a focal individual (rather than residing only within some administrative boundary) to avoid the modifiable areal unit problem (Musterd 2005); i.e. of using administrative or statistical areas to measure the level of segregation by taking a single-scalar approach.

\section{$5 \quad$ Results}

\subsection{The difference between the fertility of the Roma and the ethnic- majority population}

The fertility trends of post-communist countries before and after the fall of communism are well known and well documented (Sobotka 2011). As we know, Slovakia and Romania had relatively high fertility during the socialist era; but following the transition, a decrease in fertility rates characterised all four countries

Fig. 1: Average number of children ever born, by women's birth cohort and ethnicity in selected countries, 2011

Average number of children

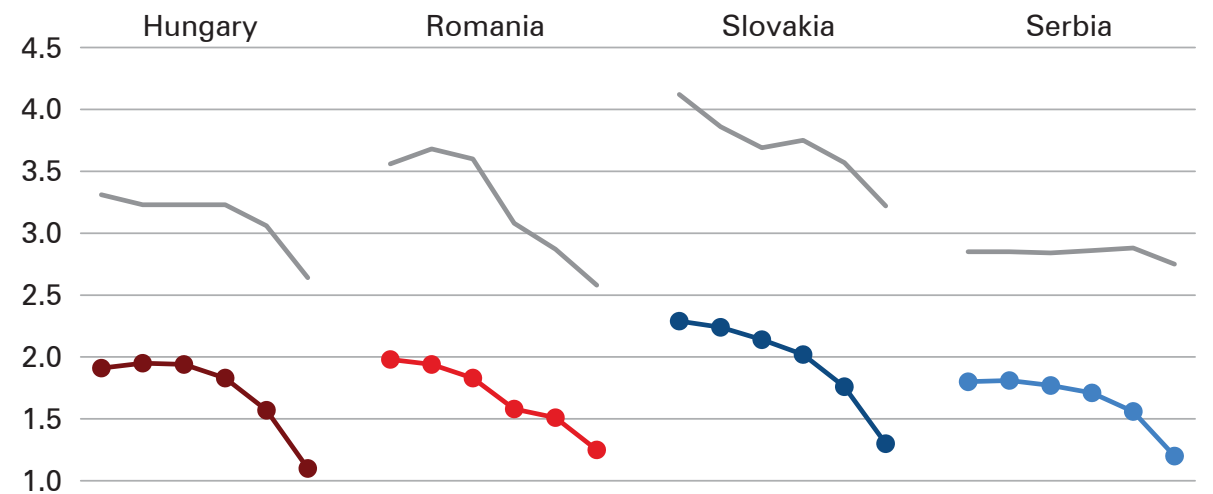

0.5

0.0

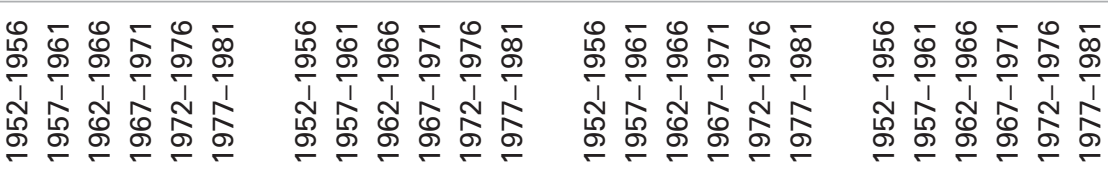

Birth cohort

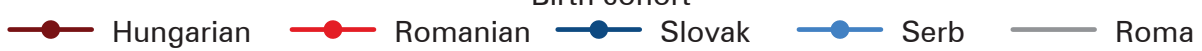

Source: Own calculation based on 2011 national population censuses from Hungary, Romania, Slovakia and Serbia. Full population data. 
included in our analysis. This trend is also clearly visible when we look at the mean number of children for birth cohorts born between 1952 and 1956 which range from 2.29 (Slovakia) to 1.83 (Serbia) (Appendix Tab. A4). This range is even smaller for birth cohorts born in 1977-1981 (aged 30-34 at the time of the 2011 census) at between 1.09 (Hungary) and 1.30 (Slovakia).

When we compare the data by ethnicity, the difference between the Roma and non-Roma population is clearly visible. The average number of children ever born to Roma women is far above the majority population's average, in all birth cohorts and in all countries (Fig. 1). Considering only those cohorts that had already completed their fertility, the ratio of cohort fertility rate (CFR) for Roma women to non-Roma women ranges from a minimum of 1.6 (in Serbia) to a maximum of 1.9 (in Romania; Fig. 1).

It is not surprising that, from the selected countries, the CFR of the majority populations is very similar. The societal and economic conditions of fertility were pretty much the same under communism, and all these countries have experienced difficult transitions to a market economy, which rapidly led to the postponement of childbearing and to low fertility. It is more striking, however, that the fertility of the ethnic minority Roma populations in the four countries shows much greater similarity to one another than to the respective majority populations. (However, the Slovak figures may be distorted by the fact that in the census, many Roma women, especially from the older cohorts, did not reveal the total number of children they had, Appendix Tab. A5). Some differences by country may be observed, however. While the Roma in Serbia have had consistently lower levels of fertility with little change over time, the fertility of Roma women from the other three countries has declined over time.

\subsection{Fertility of Roma and ethnic majority, by completed education}

Cohort fertility and level of completed education are basically inversely related according to our findings, regardless of country of residence, birth cohort, or ethnicity (Fig. 2a, 2b, 2c, 2d). ${ }^{7}$ Cohort fertility is highest among the less well educated and is lowest among the highly educated women. The correlation between fertility and educational attainment is stronger among the Roma than among the ethnic majority population, as the fertility of less well-educated Roma women is far higher than the fertility of majority women with a lower education level. Meanwhile highly educated Roma and ethnic majority women have very similar fertility rates. Consider, for example, the completed fertility of Roma women born between 1962 and 1966 (45-49 years old in 2011), by educational attainment and by country. The CFR of Roma women in Hungary with low and high education levels is 3.46 and 1.90, respectively, (Fig. 2a); 3.83 and 1.20 in Romania (Fig. 2b); 3.86 and 2.17 in Slovakia

7 However, we should bear in mind the low number of highly educated Roma women, especially among older birth cohorts. The number of highly educated Roma women is in the range of 27 87 in Hungary, 4-24 in Romania (IPUMS 10 percent sample), 12-71 in Slovakia and 6-46 in Serbia, according to birth cohort. 
(Fig. 2c); and 2.93 and 1.47 in Serbia (Fig. 2d). Meanwhile, the CFR of non-Roma women with low and high levels of education in Hungary is 2.41 and 1.75 (Fig. 2a); 2.53 and 1.19 in Romania (Fig. 2b); 2.69 and 1.78 in Slovakia (Fig. 2c); and 2.04 and 1.48 in Serbia (Fig. 2d). That is, the difference in fertility between Roma women with low and high levels of education is greater than that of the difference in the fertility of corresponding non-Roma women. As educational attainment increases, the fertility gap between Roma and non-Roma women narrows.

The difference in CFR of Roma and non-Roma women with a low education level born in 1962-1966 is 1.05 children in Hungary (Fig. 2a), 1.30 in Romania (Fig. 2b), 1.17 in Slovakia (Fig. 2c) and 0.89 in Serbia (Fig. 2d). Furthermore, the difference in CFR of Roma and non-Roma women with a high level of education born in 1962 1966 practically disappears: it is 0.15 children in Hungary, 0.01 in Romania, 0.39 in Slovakia, and -0.01 in Serbia (as the fertility of highly educated Serbian women is higher than that of Roma women). Moreover, the youngest (30-34) group of highly educated Roma women in Hungary actually has a lower fertility rate than the group

Fig. 2a: Average number of children ever born, by women's birth cohort, ethnicity and completed education, Hungary, 2011

Average number of children

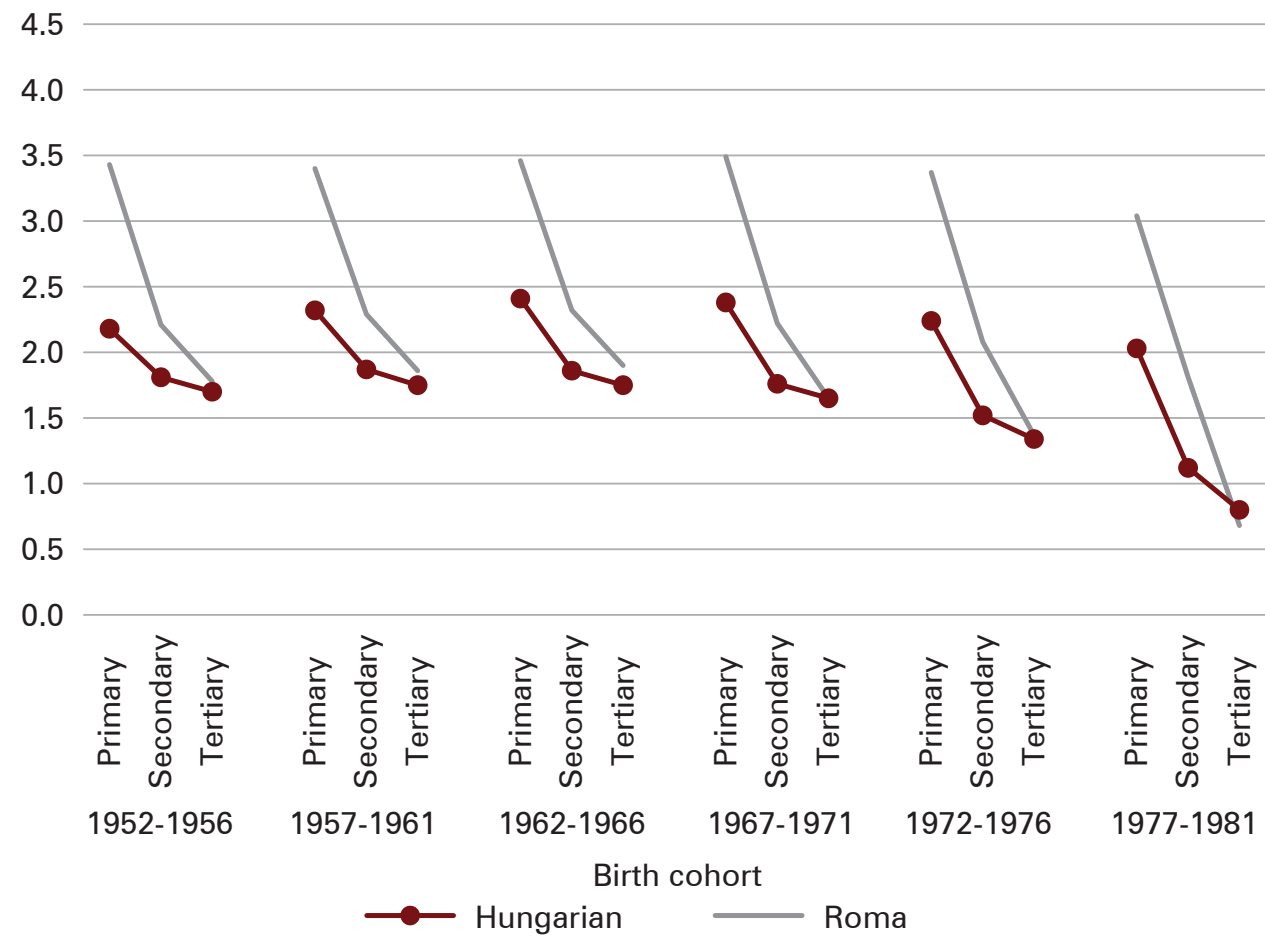

Source: Own calculation based on the 2011 Population and housing census, Hungary. Full population data. 
Fig. 2b: Average number of children ever born, by women's birth cohort, ethnicity and completed education, Romania, 2011

Average number of children

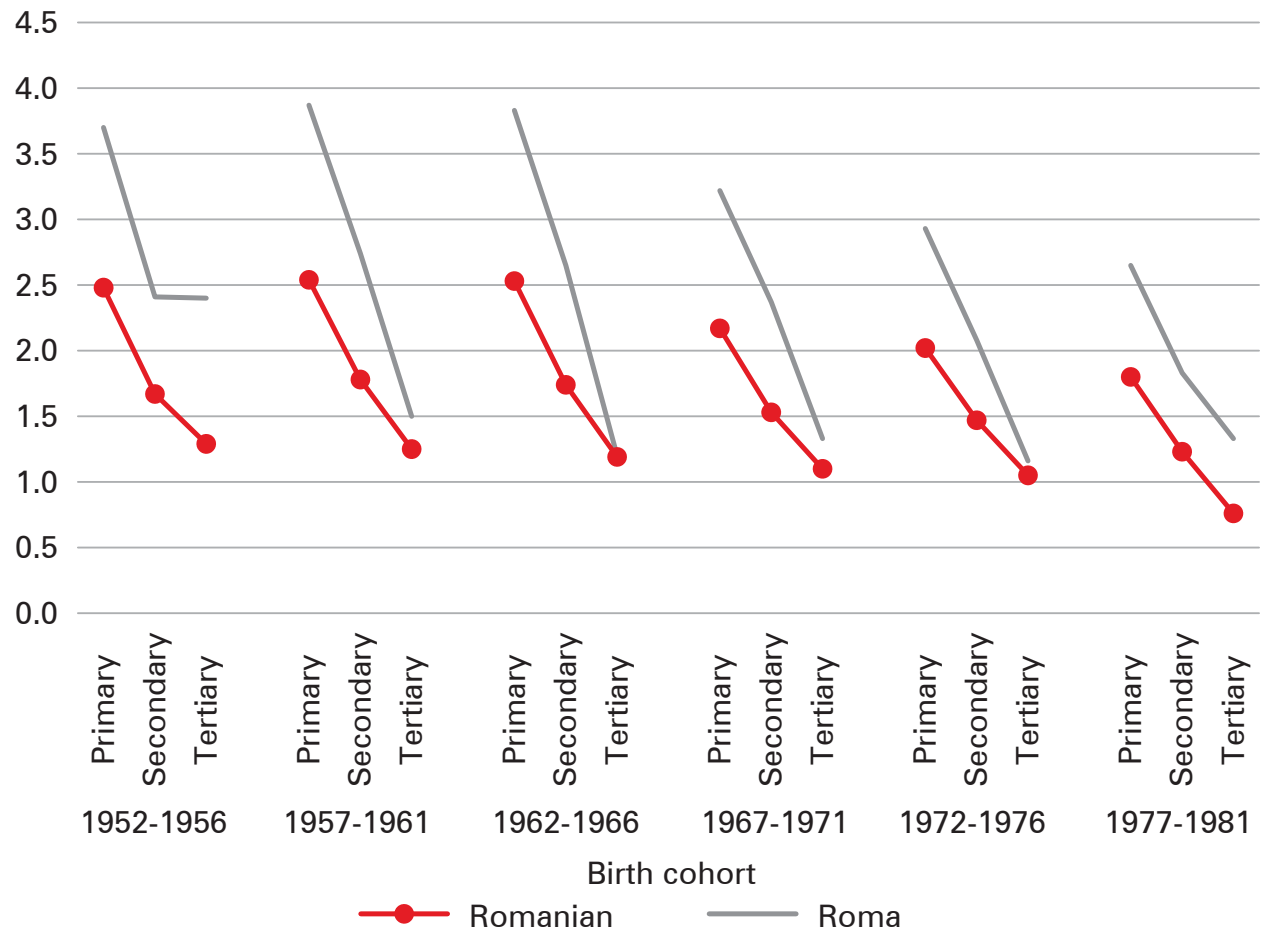

Source: Own calculation based on the 10 percent sample of the 2011 population and housing census Romania, IPUMS-International.

of highly educated Hungarian women from the same birth cohort. We observe a similar relationship in Serbia: the highly educated Roma women in the 1952-1956 and 1972-1976 birth cohorts have, on average, given birth to fewer children than Serbian women (Fig. 2d).

The picture is also similar in Romania, although there is no convergence in fertility by education among women aged 30-34 and 50-59. Without going into too much detail, we should note that we were not able to track the dimension of migration, which is especially important with regard to the youngest Romanian cohorts, and thus we cannot provide evidence on how the various migration processes influence the relationship between fertility and birth cohort, education and ethnicity.

The fertility pattern by ethnicity and education in Slovakia deviates from that found in the other three countries. It is true that women with a high level of education have fewer children than women with a low education level; but well-educated Roma women, on average, have more children than Roma women with a medium level of education in some birth cohorts. We might speculate that those well-educated 
Fig. 2c: Average number of children ever born, by women's birth cohort, ethnicity and completed education, Slovakia, 2011

Average number of children

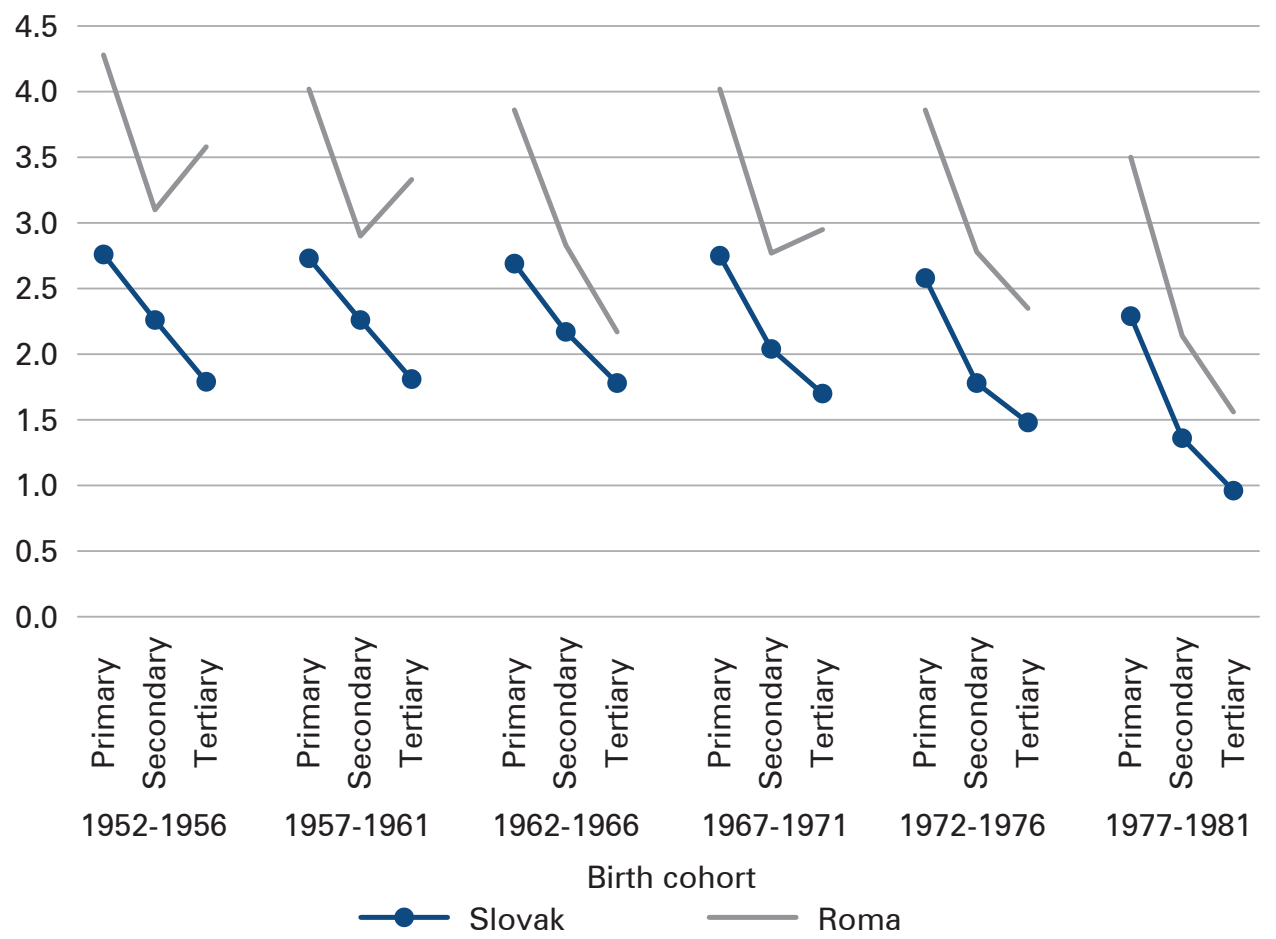

Source: Own calculation based on the 2011 Population and housing census, Slovakia. Full population data.

Roma women who had fewer children might have refused to answer the question regarding their number of children ever born because they felt uncomfortable about transgressing the norms of the Roma community, which favour women who have many children. Moreover, there are very few well-educated Roma women (especially in older cohorts). However, the convergence in the CFR of Roma and Slovak women is visible in Slovakia, too, with the increase in educational attainment.

\subsection{Fertility of Roma and ethnic majority by residential segregation in Hungary}

Our second interest in this paper is to capture the contextual effect on fertility among the Roma and ethnic majority population. We analyse this question using the Hungarian census data, as we only have access to individual-level data of residential proximity in the case of Hungary. Furthermore, we can take advantage of the methodology used in the 2011 population census with regard to ethnic identification. As the census allowed for double ethnic identification, we could 
Fig. 2d: Average number of children ever born, by women's birth cohort, ethnicity and completed education, Serbia, 2011

Average number of children

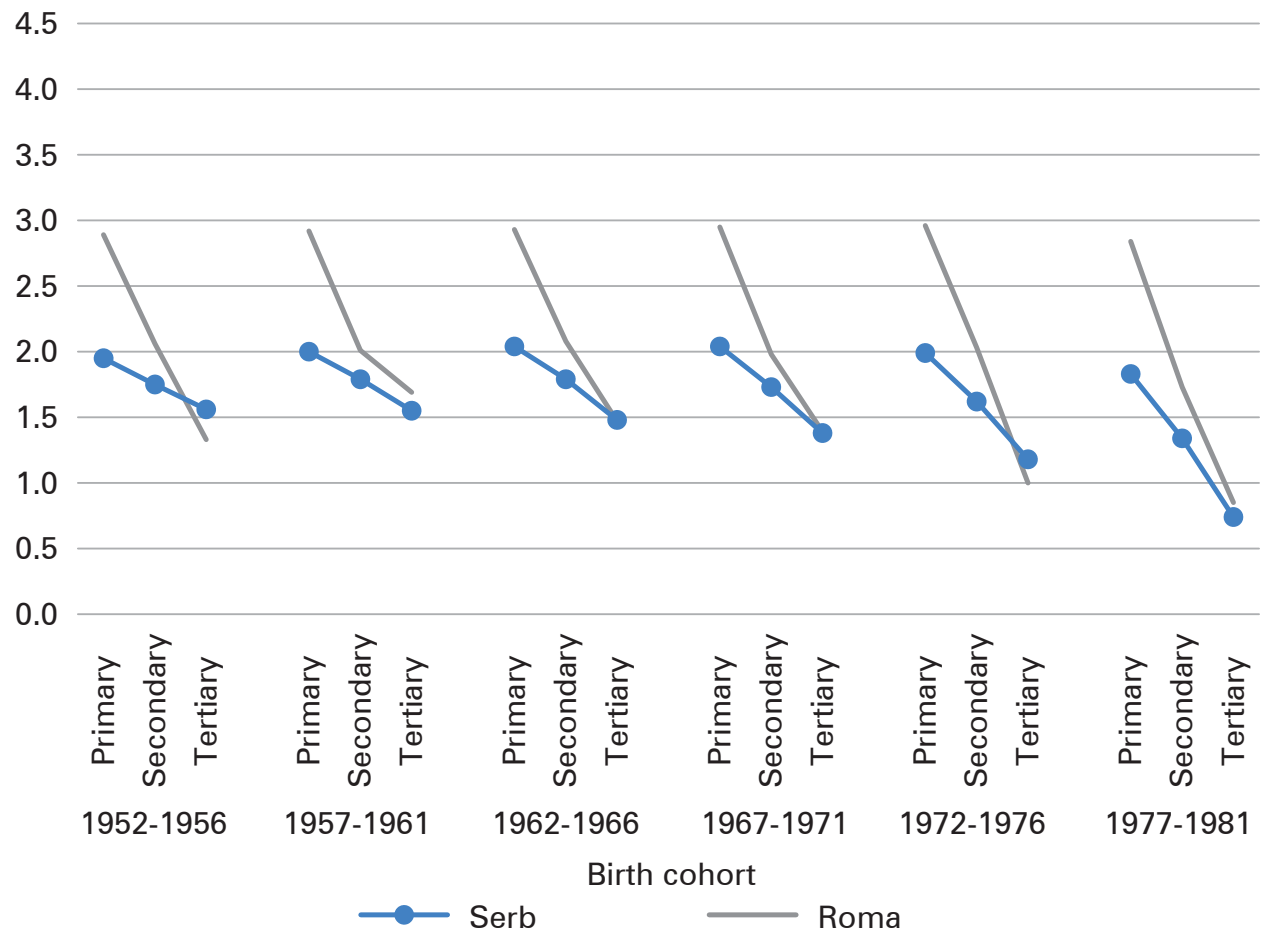

Source: Own calculation based on the 2011 Census on population, households and dwellings in the Republic of Serbia. Full population data.

enlarge the population to include those who identified themselves as Roma as their second nationality. We consider a woman to have Roma identity in this chapter if her primary or secondary nationality is Roma, or her mother tongue is Roma, or she uses the Roma language when she speaks to friends and family members, or knows the Roma language (Appendices Tab. A2 and Tab. A3). The average number of children of women with primary Roma nationality and women with secondary Roma identity do not differ significantly from each other (Appendix Tab. A6).

We measure the contextual effect in terms of ethnic-minority members' exposure to the majority population living in the same residential area. We calculated the share of the Roma population within every residential neighbourhood (census residential block) and named it the level of ethnic residential segregation of Roma women. ${ }^{8}$

8 In total, 183,398 residential neighbourhoods were defined in the 2011 Hungarian census. In our target group for analysis in this section, (i.e., 30-59-year-old women, living in a residential block with a minimum of 15 persons and at least one Roma inhabitant), the number of Roma women was 57,529 ; and the number of non-Roma Hungarian women was 877,637 . 
Fig. 3: Average number of children ever born, by women's birth cohort, ethnicity and degree of residential Roma segregation, Hungary, 2011

Average number of children

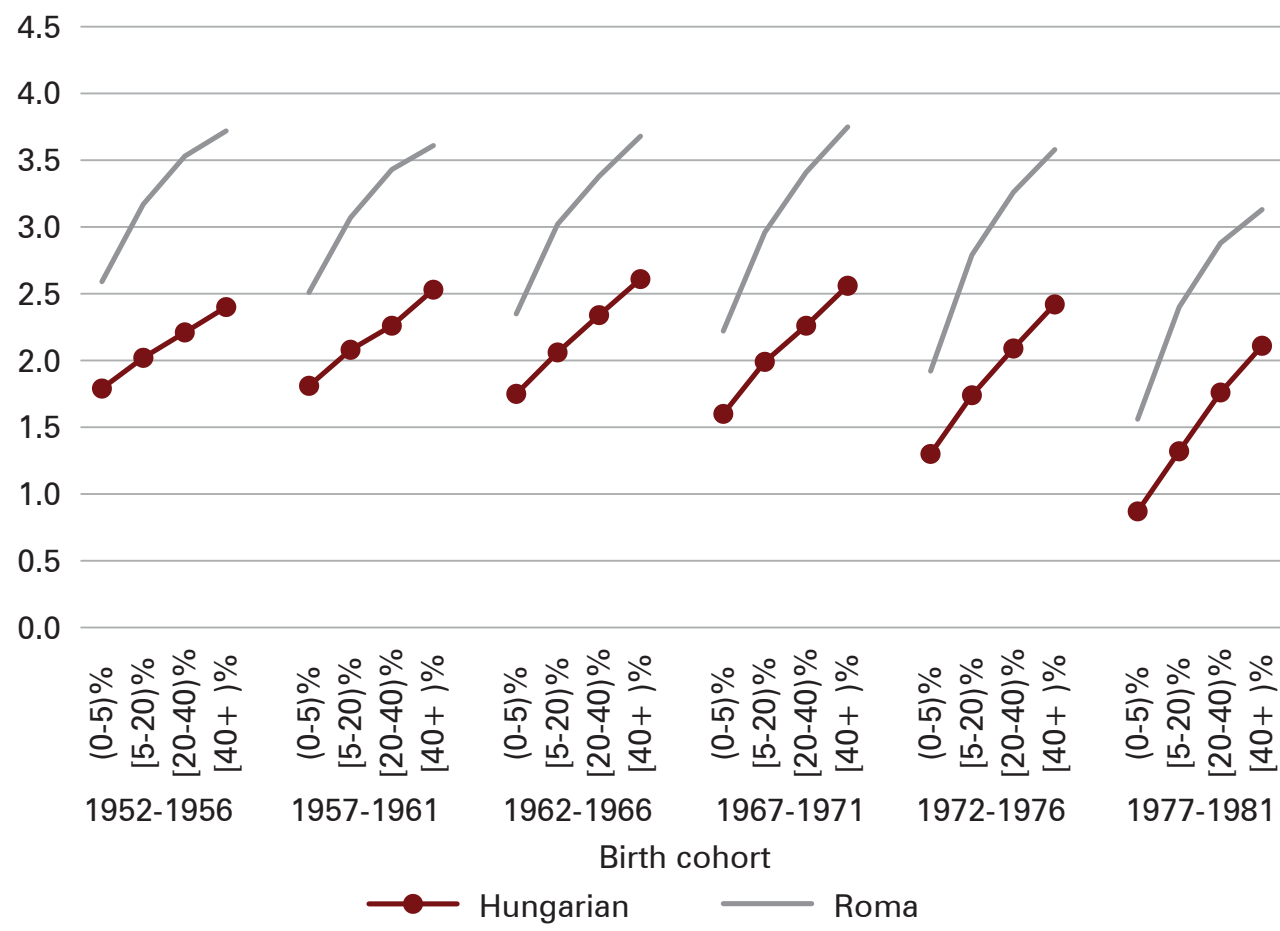

Notes: Hungarians are those who answered "Hungarian" (but not Roma) to the questions on primary or secondary ethnicity, mother tongue, language spoken with friends and family, and known language. Roma are those who answered "Roma" (or beás, oláh cigány, or any other Roma clan name) to the questions on primary or secondary ethnicity, mother tongue, language spoken with friends and family, and known language.

Source: Own calculation based on 2011 Population and housing census, Hungary, full population data.

The relationship between cohort fertility and the level of residential segregation is positive, regardless of birth cohort and ethnicity. The greater the share of Roma in a residential neighbourhood, the higher the average number of children ever born to both Roma and non-Roma Hungarian women.

The differences in cohort fertility between the most and the least segregated neighbourhoods are larger among Roma than among non-Roma Hungarian women, regardless of birth cohort. While this difference ranges from 0.61 to 1.24 for different birth cohorts among the ethnic majority population, the figure is between 1.10 and 1.66 among Roma birth cohorts. It is also clear from Figure 3 that the cohort fertility of Roma women is higher than that of non-Roma Hungarian women at all degrees of segregation. However, a clear convergence can be observed: the lower the level of 
segregation, the smaller the fertility gap between Roma and non-Roma Hungarian women. While the fertility difference between the Roma and non-Roma in the most segregated neighbourhoods ranges from 1.02 to 1.32 (depending on the birth cohort), the difference is only between 0.60 and 0.80 in the least segregated areas.

\subsection{Joint effects of completed education and degree of residential segregation in Hungary}

The completed fertility of three different cohorts (1952-1961; 1962-1971; and 19721981) by completed education and degree of residential segregation enables us to disentangle possible reinforcing effects.

The two ends of the educational spectrum show quite different relations (Fig. 4). On the one hand, higher education seems to determine the level of fertility quite unequivocally: the completed fertility of the ethnic majority non-Roma Hungarian women is similar to that of the Roma women, and the degree of residential segregation does not add much to the variation. The fertility difference between highly educated Roma and majority women is relatively constant and small. Minor fluctuations can be observed among Roma women by degree of residential segregation due to the low number of highly educated Roma women living in segregated areas, especially among the oldest birth cohorts. ${ }^{9}$ All in all, ethnicity makes no great difference among women with a high level of education.

At the other end of the scale, residential segregation clearly influences the level of fertility among women who only have primary education. The higher the proportion of Roma in a neighbourhood, the higher the fertility of women. And this relationship is the same for Roma and non-Roma women. However, ethnicity also makes a difference: the cohort fertility of Roma women with a low level of education is always higher than that of less-educated non-Roma Hungarian women, regardless of the degree of residential segregation.

The relationship between cohort fertility and residential segregation differs between Roma and non-Roma Hungarian women with a medium level of education. We find a positive relationship among Roma women: fertility rises as the level of segregation increases. Meanwhile, barely any positive relationship can be observed among non-Roma women: fertility remains relatively constant as the degree of residential segregation increases. At this level of education, a divergence in cohort fertility is measured between Roma and non-Roma Hungarian women as residential segregation increases: this divergence is caused by an increase in the cohort fertility of Roma women.

9 The number of well-educated Roma women living in segregated areas was low among the oldest birth cohort (i.e. born in 1952-1961): there were merely four in neighbourhoods where the share of the Roma population was 20-40 percent; and three in neighbourhoods where the share of Roma was over 40 percent. However, there were 22 well-educated Roma women born between 1972-1981 living in the most-segregated neighbourhoods with proportion of Roma population higher than 40 percent. 
Fig. 4: Average number of children ever born by women's birth cohort, ethnicity, completed education and degree of segregation, Hungary, 2011
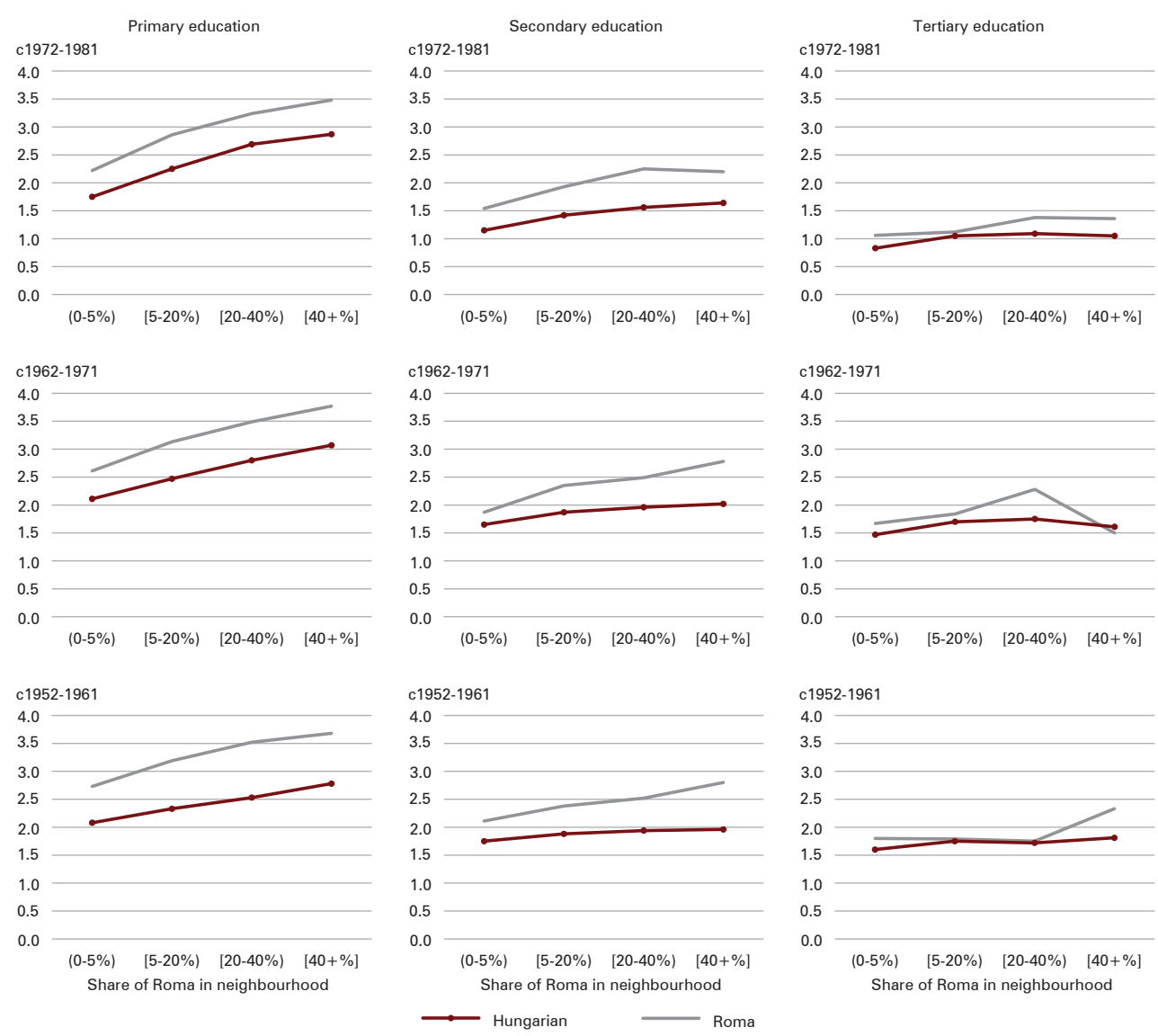

Notes: Hungarians are those who answered "Hungarian" (but not Roma) to the questions on primary nationality, secondary nationality, mother tongue, language spoken with friends and family, and known language. Roma are those who answered "Roma" (or beás, oláh cigány, or any other Roma clan name) to the questions on primary nationality, secondary nationality, mother tongue, language spoken with friends and family, and known language.

Source: Own calculation based on the 2011 Population and housing census, Hungary, full population data.

\section{Discussion}

The average number of children ever born to Roma women is far above the ethnic majority population's average in all birth cohorts and in each selected country. At the same time, the distinct fertility pattern of Roma - namely, early and high fertility - is very similar in these four countries. There may be several reasons for this. Overall, Roma fertility could be similar in the four countries because the 
composition of the populations is also similar, or they live in similar contextual conditions, or their subculture is similar. At the same time, the Roma population itself could be very heterogeneous due to institutional settings and resources, tradition and values; thus, the demographic behaviour of different Roma subgroups may also be different within particular countries. However, as the share of individuals with advanced socio-economic status is low within the Roma population in these countries, their behaviour are hardly visible within the overall Roma population. Therefore, the overall Roma fertility is consistently higher than that of the ethnic majority population in these four selected countries. These general findings namely, the very similar patterns of fertility within the Roma population of different countries, controlled for birth cohort (and by educational attainment) - may be seen as an indicator of the cultural conditions related to the behaviour of Roma and their pronatalist attitude.

The Roma population may be divided into subgroups based on different factors. In our analysis, we focus on the aspects that have already been raised in theoretical assumptions explaining the fertility differences between ethnic minoritymajority populations. We have outlined three major concepts to understand these differences. The first concept - known as the social characteristics hypothesis states that it is not ethnicity per se, but rather social characteristics that determine fertility. From the point of view of our analysis, the "strong form" of this concept would be supported, if the fertility of Roma and ethnic majority populations were the same at all levels of educational attainment - assuming that educational level is a good proxy for social status. Our results clearly show that the level of completed education of women influences fertility in all the countries examined: the higher the education of Roma women, the lower their fertility. Besides, the fertility gap between Roma and respective ethnic majority populations narrows as the level of education increases in all countries: the fertility of highly educated Roma and nonRoma women is the same, or at least converges to a large degree. We conclude that high Roma fertility reflects compositional effects: the high fertility of the Roma population is certainly due to the fact that the proportion of less educated women is much higher among them than the proportion of those with medium or high levels of education. The social characteristics hypothesis is only relevant among the highly educated women: the highly educated Roma and majority population fertility is not different, but the less educated Roma and majority women's fertility is. This means that the "strong form" of the social characteristics hypothesis is not supported by our results, but we find evidence supporting the "weak form" of this hypothesis (Johnson 1979: 1388).

The minority hypothesis states that the minority position has an independent effect on fertility. If minority people wish to acquire higher social status, they have to invest their social and economic resources more heavily than others, and in order to do so they may have to limit their fertility. The "strong form" of the minority status hypothesis would be supported by our analysis if the highly-educated Roma women had lower fertility than that of highly educated non-Roma women, while less well-educated Roma women's fertility would be higher than majority women's fertility. The "weak form" of it would be supported, however, if highly educated 
Roma women had lower fertility than highly educated non-Roma women, while no fertility difference would be found between groups at the lower end of the education spectrum. Our results suggest that, in general, neither the "strong form" nor the "weak form" of the minority status hypothesis is supported by the 2011 census data in these four CCE countries. Highly educated Roma women's fertility is not always lower than the fertility of highly educated ethnic majority women (Johnson 1979: 1388). This is only the case among women born in 1977-1981 in Hungary, and among women born in 1952-1956 and in 1972-1976 in Serbia; thus, only in these subgroups does the "strong form" of minority group status hypothesis appear justified.

The minority position may also influence minorities' fertility through the minoritymajority relationship. Interacting with other fringes of the society may differentiate the viewpoints of minority individuals, as people living in close proximity to them may have different social characteristics, values, attitudes and opinions. Certainly, individuals living in minority women's neighbourhoods may also be heterogenous. They may likewise have higher or lower degrees of socio-economic status and may equally represent pronatalist or non-pronatalist values. Thus, women (and their families) may be affected by different or even contradictory attitudes and behaviours. Besides, it is an over-simplification to assume that this contextual or environmental (or neighbourhood) influence is only a subcultural one. The fact that residential segregation is closely related to economic deprivation also suggests the presence of structural factors. With all this in mind we assume, however, that exposure to a given environment affects individuals' (and families') attitudes and behaviour. And we consider this environmental or neighbourhood influence primarily as a proxy for the subcultural influence in the case of Roma minorities. The exposure to the ethnic majority populations' environment is measured through the composition of the population by ethnicity: that is, the share of Roma in given neighbourhoods. This indicator was considered to measure the level of ethnic residential segregation in our paper. The results show that the relationship between the cohort fertility and the level of ethnic residential segregation is positive, regardless of birth cohort and ethnicity. The greater the share of Roma in a residential neighbourhood, the higher the average number of children ever born to both Roma and non-Roma women. However, the fertility of Roma women is higher than that of the fertility of ethnicmajority women, regardless of the degree of residential segregation.

These results may serve as arguments for the subcultural hypothesis, since the fertility of both Roma and majority women residing in ethnically segregated neighbourhoods is higher than that in less segregated areas. Moreover, the fertility of majority women living in ethnically segregated neighbourhoods is also higher than that of those living in less segregated neighbourhoods. At first glance, it may seem surprising that non-Roma Hungarian women living in such areas also have high fertility, but some studies confirm that members of the majority population tend to behave similarly to the minority where this minority represents a substantial share of the population (Gyenei 1993). However, we should bear in mind that Roma people living in segregated areas could have self-identified as non-Roma Hungarians; or that segregated areas, in general, are also economically disadvantaged, where both Roma and non-Roma have low education levels, inducing high fertility. 
We also looked at the minority-majority fertility gap both by educational level and ethnic residential segregation. The results suggest that these two factors may exert a different force at the two ends of the education distribution. At the higher end of the educational hierarchy, there is no fertility gap between Roma and nonRoma women, at different levels of segregation. At the lower end of the social hierarchy, both exposure to majority behaviour and ethnicity matter. In addition, ethnic-majority women with low educational levels exhibit increasingly minoritylike fertility behaviour. It seems that "behavioural acculturation" takes place at this end of the social status hierarchy, as the fertility of non-Roma majority women with low education levels depends on the level of ethnic residential segregation. However, the completion of secondary education renders majority women immune to exposure to ethnic-minority behaviour. As for Roma women, having secondary education clearly reduces their fertility, but the influence of residential segregation remains.

\section{Conclusion}

As noted in the introduction, we have contributed to a better understanding of the characteristic fertility of a quite sizeable minority group - the Roma. We have done this in a comparative manner, including four of the five countries of Central and Eastern Europe in our analysis, the ones with a sizable Roma population: Hungary, Slovakia, Romania and Serbia (Bulgaria was not included in the analysis because no relevant statistics were available to us). We have shown that the fertility of Roma in all these countries is very similar in terms of both the rate of fertility and cohort change. We have also shown, comparatively, that the level of education has a strong impact on level of fertility among Roma. Lastly, we have demonstrated, based on the case of Hungary, that exposure to ethnic-majority behaviour also has a large impact. To our knowledge, no analysis has so far been conducted that comparatively explores the fertility of the Roma minority at the birth cohort level in the context of former communist countries, using census (quasi full population) data. We are not aware of any analysis that systematically compared cohort fertility among Roma and non-Roma majority women by educational level either across several countries. Nor are we aware of any research that reviewed the joint effect of educational level and ethnical-residential (neighbourhood) segregation on birth cohort fertility among Roma and the non-Roma majority population at the national level. Our analyses of these correlations and contexts may provide additional insights to fertility research on minority populations.

Our analyses and interpretations have several limitations. First of all, identification of the Roma population is far from unequivocal; moreover, we have non-negligible missing values with regard to the question of nationality from the censuses; both these factors could have consequences for our results. Secondly, we should be very careful about interpreting our cross-sectional associations. The well-known endogeneity problem, especially in the case of education and fertility, may weaken the relevance of the social characteristics concept. Thirdly, it may be oversimplistic 
to interpret segregation as a cultural factor: the fact that residential segregation is closely related to economic deprivation hints at the role of structural factors. Lastly, the non-inclusion of the time dimension in the analysis - i.e., how long people have lived in a particular place - may also influence the role of structural and cultural factors. The inclusion of additional contextual and individual-level factors would certainly lead to more detailed results. It falls to further research to overcome the limitations mentioned and to arrive at a more refined understanding of Roma fertility.

\section{Acknowledgements}

Thanks to the two unknown reviewers for their valuable comments and suggestions.

\section{References}

Andersson, Eva K.; Lyngstad, Torkild Hovde; Sleutjes, Bart 2018: Comparing patterns of Segregation in North-Western Europe: A Multiscalar Approach. In: European Journal of Population 34: 151-168. https://doi.org/10.1007/s10680-018-9477-1

Andorka, Rudolf 1987: Gyermekszám a fejlett országokban [Fertility in Advanced Societies]. (Expanded version of Andorka 1978). Budapest: Gondolat.

Balbo, Nicoletta; Billari, Francesco C.; Mills, Melinda 2013: Fertility in advanced societies: A review of research. In: European Journal of Population/Revue européenne de Démographie 29,1: 1-38. https://doi.org/10.1007/s10680-012-9277-y

Battaglia, Marianna; Chabé-Ferret, Bastien; Lebedinski, Lara 2021: Segregation, fertility, and son preference: the case of the Roma in Serbia. In: Journal of Demographic Economics 87,2: 233-260. https://doi.org/10.1017/dem.2020.8

Berevoescu, lonica et al. 2002: Indicatorii privind comunitatile de romi din Romania [Indicators for the Roma Communities of Romania]. Bucharest: Research Institute for the Quality of Life.

Bezin, Emeline; Chabé-Ferret, Bastien; De La Croix, David 2018: Strategic Fertility, Education Choices and Conflicts in Deeply Devided Societies. Discussion Paper 201811. Institut de Recherches Économiques et Sociales de I'Université catholoque de Louvain.

Chabé-Ferret, Bastien; Ghidi, Paolo Melindi 2013: Differences in fertility behaviour and uncertainty: An economic theory of minority status hypothesis. In: Journal of Population Economics 26: 887-905. https://doi.org/10.1007/s00148-012-0434-8

Dubuc, Sylvie 2017: Fertility and education among British Asian women: a success story of social mobility? In: Vienna Yearbook of Population Research 15: 269-291. https://doi.org/10.1553/populationyearbook2017s269

Durst, Judit 2006: Kirekesztettség és gyermekvállalás [Social exclusion and reproduction]. PhD Thesis. Corvinus University, Budapest.

Durst, Judit 2011: 'What makes us Gypsies, who knows...?!': Ethnicity and reproduction. In: Stewart, Michael; Rövid, Márton (Eds): Multi-disciplinary Approaches to Romany Studies. Budapest: Central European University. 
European Commission 2011: An EU framework for national Roma integration strategies up to 2020. Communication From the Commission to the European Parliament, the Council, the European Economic and Social Committee and the Committee of the Regions 173.

Eurostat 2018: Total fertility rate. Total fertility rate online data code: TPS00199. [DEMO FIND] Luxembourg: Eurostat, the statistical office of the European Union [https:// ec.europa.eu/eurostat/databrowser/product/view/DEMO_FIND, 06.10.2021].

Forste, Renata; Tienda, Marta 1996: What's behind racial and ethnic fertility differentials? In: Population and Development Review 22: 109-133.

FRA; UNDP 2012: The situation of Roma in 11 EU Member States. Survey results at a glance. European Union Agency for Fundamental Rights [https://fra.europa.eu/sites/ default/files/fra_uploads/2099-FRA-2012-Roma-at-a-glance_EN.pdf, 17.08.2021].

FRA; UNDP 2018: Regional Roma Survey 2017: Country fact sheets. Roma at a glance. Serbia. European Union Agency for Fundamental Rights.

Frejka, Tomas; Sardon, Jean-Paul 2003: Fertility trends and prospects in Central and Eastern Europe: The cohort perspective. In: Kotowska, Irena E.; Jóźwiak, Janina (Eds.): Population of Central and Eastern Europe: Challenges and opportunities. Warsaw: Statistical Publishing Establishment: 91-116.

Gamella, Juan Francesco 2018: Marriage, Gender and Transnational Migrations in Fertility Transitions of Romanian Roma Women. In: Intersections. East European Journal of Society and Politics 4,2: 57-85. https://doi.org/10.17356/ieejsp.v4i2.389

Goldscheider, Calvin; Uhlenberg, Peter R. 1969: Minority group status and fertility. In: American Journal of Sociology 74,4: 361-372. https://doi.org/10.1086/224662

Gyenei, Márta 1993: Létminimum alatt-Jajhalom I. Below the minimum standard of living-Jajhalom. In: Statisztikai Szemle: 16-31.

Hablicsek, László 2007: Kísérleti számítások a roma lakosság területi jellemzőinek alakulására és 2021-ig történő elörebecslésére [Experimental calculations for the development of territorial characteristics of the Roma population and their forecast until 2021]. In: Demográfia 50,1: 7-54.

Haug, Werner; Courbage, Youssef; Compton, Paul 1998, 2000: The demographic characteristics of national minorities in certain European states. Vol. 1-2. Strasbourg: Council of Europe. Demography. Population studies 30-31.

Havas, Gábor; Kemény, István; Kertesi, Gábor 1998: A relatív cigány a klasszifikációs küzdötéren [The relative gypsy on the classification arena]. In: Kritika 3: 31-33.

Husz, lildikó 2011: Alacsony végzettség - sok gyerek? A magas termékenység néhány területi és etnikai aspektusáról [Low educational attainment leads to many children? About some regional and ethnic aspects of high fertility]. In: Demográfia 54,1: 5-22.

IPUMS 2018: Minnesota Population Center. Integrated Public Use Microdata Series, International: Version 7.0 [dataset]. Minneapolis, MN: IPUMS. Original data producer: National Institute of Statistics, Romania. https://doi.org/10.18128/D020.V7.0

IPUMS 2019a: Minnesota Population Center. Integrated Public Use Microdata Series, International: Version 7.0 [dataset]. Minneapolis, MN: IPUMS. Sampling Error Estimation [https://international.ipums.org/international/sample_design_summary. shtml, 06.10.2021].

IPUMS 2019b: Minnesota Population Center. Integrated Public Use Microdata Series, International: Version 7.0 [dataset]. Minneapolis, MN: IPUMS. IPUMS User Note: Issues Concerning the Calculation of Standard Errors (i.e., variance estimation) Using IPUMS Data Products. https://doi.org/10.18128/D020.V7.0 
Jalovaara, Marika et al. 2019: Education, gender, and cohort fertility in the Nordic countries. In: European Journal of Population 35,3: 563-586. https://doi.org/10.1007/s10680-018-9492-2

Johnson, Nan E. 1979: Minority-group status and the fertility of black Americans, 1970: A new look. In: American Journal of Sociology 84,6: 1386-1400. https://doi.org/10.1086/226939

Kalibova, Kveta 2000: The demographic characteristics of Roma/Gypsies in selected countries in Central and Eastern Europe. In: The Demographic Characteristics of National Minorities in Certain European States 2. Council of Europe: 169-206.

Kemény, István; Janky, Béla 2003: A cigány nemzetiségi adatokról [On Roma ethnicity data]. In: Kisebbségkutatás 2: 309-315.

Kennedy, Robert E. 1973: Minority group status and fertility: The Irish. In: American Sociological Review 38,1: 85-96. https://doi.org/10.2307/2094333

Koytcheva, Elena; Philipov, Dimiter 2008: Bulgaria: Ethnic differentials in rapidly declining fertility. In: Demographic Research 19: 361-402. https://doi.org/10.4054/DemRes.2008.19.13

Kulu, Hill et al. 2019: A decade of life-course research on fertility of immigrants and their descendants in Europe. In: Demographic Research 40: 1345-1374. https://doi.org/10.4054/DemRes.2019.40.46

Kushen, Robert (Ed.) 2015: Roma Inclusion Index 2015. Decade of Roma Inclusion Secretariat Foundation, Budapest.

Ladányi, János; Szelényi, Iván 2001: The social construction of Roma ethnicity in Bulgaria, Romania and Hungary during market transition. In: Review of Sociology 7,2: 79-89. https://doi.org/10.1556/revsoc.7.2001.2.5

Martin, Todd Forrest 2020: Toward a Theory of Fertility and Ethnic Social Capital. In: Marriage \& Family Review 56,1: 1-19. https://doi.org/10.1080/01494929.2019.1630046

Musterd, Sako 2005: Social and ethnic segregation in Europe: Levels, causes and effects. In: Journal of Urban Affairs 27,3: 331-348. https://doi.org/10.1111/j.0735-2166.2005.00239.x

Nestorová Dická, Janetta 2021: Demographic Changes in Slovak Roma Communities in the New Millennium. In: Sustainability 13,7: 3735. https://doi.org/10.3390/su13073735

Obádovics, Csilla et al. 2019: A roma népesség előreszámítása 2050-ig. Jelentés a Belügyminisztérium részére [Population projection for the Roma population in Hungary by 2050. Report to the Ministry of the Interior]. Budapest.

Pénzes, János; Tátrai, Patrik; Pásztor, István Zoltán 2018: A roma népesség területi megoszlásának változása Magyarországon az elmúlt évtizedekben [Changes in the Spatial Distribution of the Roma Population in Hungary During the Last Decades]. In: Területi statisztika 58,1: 3-26 [https://www.ksh.hu/statszemle_archive/ terstat/2018/2018_01/ts580101.pdf, 06.10.2021].

Pew Research Center 2017: Religious belief and national belonging in Central and Eastern Europe. Pew Research Center report.

Portes, Alejandro; Zhou, Min 1993: The New Second Generation: Segmented Assimilation and Its Variants. In: Annals of the American Academy of Political and Social Science 530: 74-96. https://doi.org/10.1177/0002716293530001006

Potančoková, Michaela et al. 2008: Slovakia: Fertility between tradition and modernity. In: Demographic Research 19: 973-1018. https://doi.org/10.4054/DemRes.2008.19.25 
Preda, Mihaela-Daniela 2010: Demographic behaviour of the Roma population between tradition and modernity. Case Study: Oltenia Region, Romania. In: Human Geographies 4,1: 105-119.

Schwartz, Seth J. et al. 2010: Rethinking the concept of acculturation: implications for theory and research. In: American Psychologist 65,4: 237-251. https://doi.org/10.1037/a0019330

Shain, Michelle 2019: Understanding the demographic challenge: Education, orthodoxy and the fertility of American Jews. In: Contemporary Jewry 39,2: 273-292. https://doi.org/10.1007/s12397-018-9249-6

S/y, F. David 1970: Minority-group status and fertility: An extension of Goldscheider and Uhlenberg. In: American Journal of Sociology 76,3: 443-459. https://doi.org/10.1086/224951

Small, Mario Luis; Harding, David; Lamont, M Michèle 2010: Reconsidering Culture and Poverty. In: ANNALS of the AmericanAcademy of Political and Social Science 629,1: 6-27. https://doi.org/10.1177/0002716210362077

Sobotka, Tomáš 2011: Fertility in Central and Eastern Europe after 1989: Collapse and gradual recovery. In: Historical Social Research/Historische Sozialforschung 36,2: 246-296. https://doi.org/10.12759/hsr.36.2011.2.246-296

Sobotka, Tomáš et al. 2008: Czech Republic: A rapid transformation of fertility and family behaviour after the collapse of state socialism. In: Demographic Research 19: 403-454. https://doi.org/10.4054/DemRes.2008.19.14

Šprocha, Branislav 2017: Rómska populácia na Slovensku a kohortná plodnost' rómskych žien podla výsledkov sčítania obyvatel'ov, domov a bytov 2011 [The Roma population of Slovakia and the cohort fertility of Roma women according to the results of the 2011 population and household census]. In: Demografie 59,2: 118-131.

Šprocha, Branis/av; Tišliar, Pavol 2019: Fertility and religious belief: old and new relationships in Slovakia. In: Journal for the Study of Religions \& Ideologies 18,52: 63-79.

Šproha, Branislav; Durček, Pavol 2017: Rómovia na Slovensku v sčítaniach obyvatel'ov 1980-2011 [Roma in Slovakia in the census 1980-2011] Bratislava. Available: INFOSTAT.

Szabó, Laura; Kiss, Igor; Spéder, Zsolt; Sprocha, Branislav 2017: Fertility of minorities in Central and Eastern European countries. Presentation at the Fertility of Migrants and Minorities Workshop, 6-8 February, 2017. Leibniz University: Hanover.

UNDP/ILO 2001: Multi-country survey of Roma population in Central and Eastern Europe [http://roma.undp.sk, 06.10.2021].

Vaňo, Boris 2002: Projection of Roma Population in Slovakia until 2025. Bratislava: Institute of Informatics and Statistics Demographic Research Centre: 38.

Wilson, Ben 2019: The intergenerational assimilation of completed fertility: comparing the convergence of different origin groups. In: International Migration Review 53,2: 429-457. https://doi.org/10.1177/0197918318769047

Wilson, Ben 2020: Understanding how immigrant fertility differentials vary over the reproductive life course. In: European Journal of Population 36,3: 465-498. https://doi.org/10.1007/s10680-019-09536-x

Wilson, Ben; Kuha, Jouni 2018: Residential segregation and the fertility of immigrants and their descendants. In: Population, Space and Place 24,3: e2098. https://doi.org/10.1002/psp.2098

Zamfir, Cătălin; Preda, Marian (Eds.) 2002: Romii în România [Roma in Romania]. Bucharest: Editura Expert. 
Laura Szabó, PhD ( $\varangle)$, Prof. Dr. Zsolt Spéder. Hungarian Demographic Research Institute. Budapest, Hungary. E-mail: szabo@demografia.hu; speder@demografia.hu

URL: http://demografia.hu/en/staff-szabo-laura http://demografia.hu/en/staff-speder-zsolt

Igor Kiss, PhD student. University Pécs, Doctoral School of Demography and Sociology. Bečej, Serbia. E-mail: kiss.igor@gmail.com

URL: https://doktori.hu/index.php?menuid=192\&sz_ID =14799\&lang =EN

Dr. Branislav Šprocha. Centre of Social and Psychological Sciences SAS. Bratislava,

Slovakia. E-mail: branislav.sprocha@gmail.com

URL: https://www.sav.sk/?lang=en\&doc $=$ user-org-user\&user_no $=7429$ 
Fertility of Roma Minorities in Central and Eastern Europe

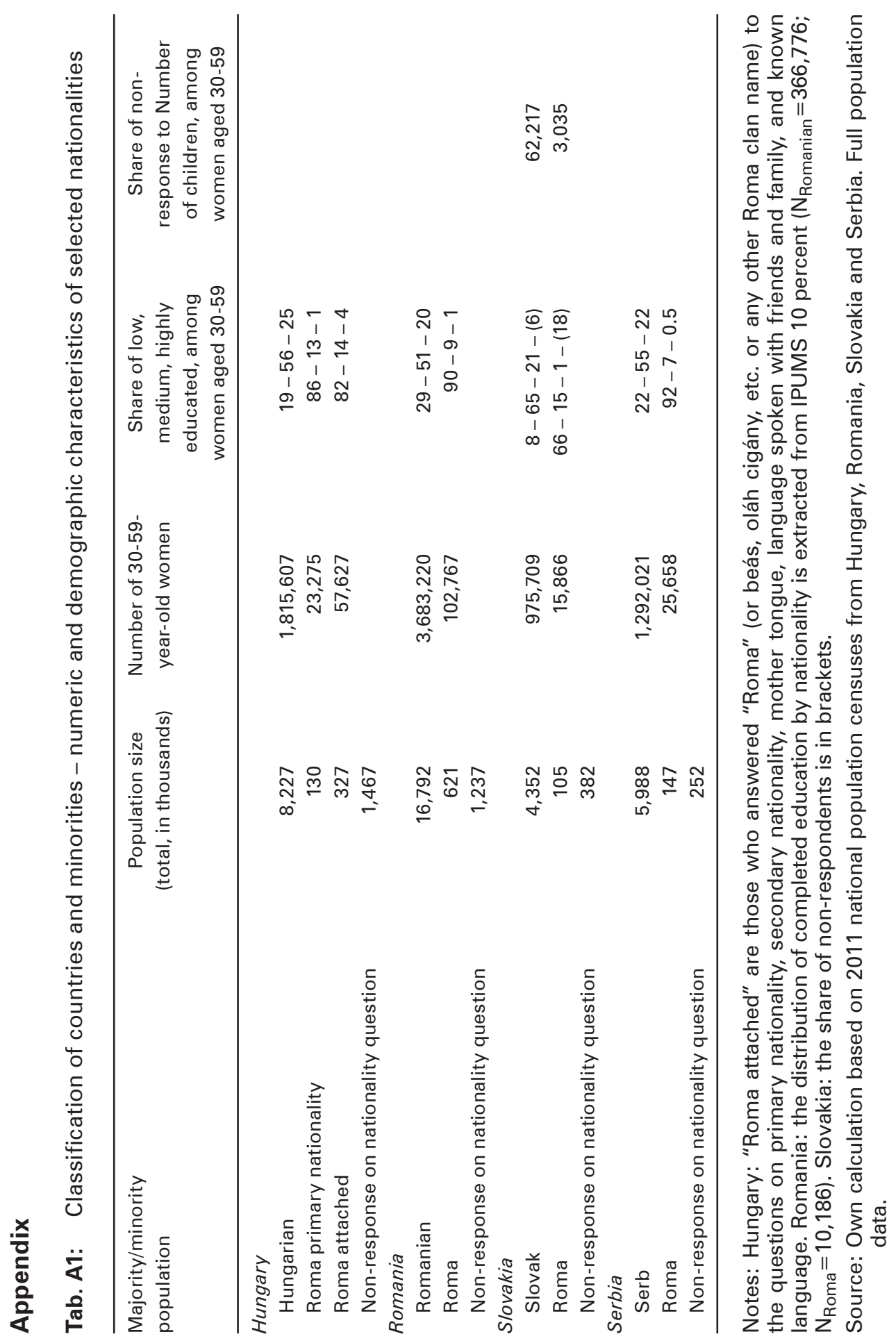


Tab. A2: The nationality question in 2011 national censuses in Hungary, Slovakia, Romania and Serbia

\begin{tabular}{|c|c|c|c|c|}
\hline Country & Type of question & $\begin{array}{l}\text { Number } \\
\text { of questions }\end{array}$ & Question(s) & Answer categories \\
\hline Hungary & Not compulsory & 2 & $\begin{array}{l}\text { Which nationality do you } \\
\text { feel you belong to? } \\
\text { Do you think you belong } \\
\text { to another nationality } \\
\text { in addition to what you } \\
\text { marked above? }\end{array}$ & $\begin{array}{l}\text { Closed answer with } 18 \\
\text { nationalities, with the } \\
\text { category Gipsy/Roma } \\
\text { among them, and the } \\
\text { open-ended "other, } \\
\text { namely: ..." category } \\
\text { offered. }\end{array}$ \\
\hline Slovakia & Compulsory & 1 & Nationality & $\begin{array}{l}\text { Closed answer with } 14 \\
\text { nationalities, with the } \\
\text { category Romani among } \\
\text { them, and the open- } \\
\text { ended "other" category } \\
\text { offered. }\end{array}$ \\
\hline Romania & Not compulsory & 1 & $\begin{array}{l}\text { What ethnic group does } \\
\text { the person consider to } \\
\text { belong to? }\end{array}$ & $\begin{array}{l}\text { Open-ended question, } \\
\text { the enumerators coded } \\
\text { them into categories. }\end{array}$ \\
\hline Serbia & Not compulsory & 1 & National affiliation & $\begin{array}{l}\text { Open-ended question, } \\
\text { the enumerators coded } \\
\text { them into categories. }\end{array}$ \\
\hline
\end{tabular}

Source: Own design. 


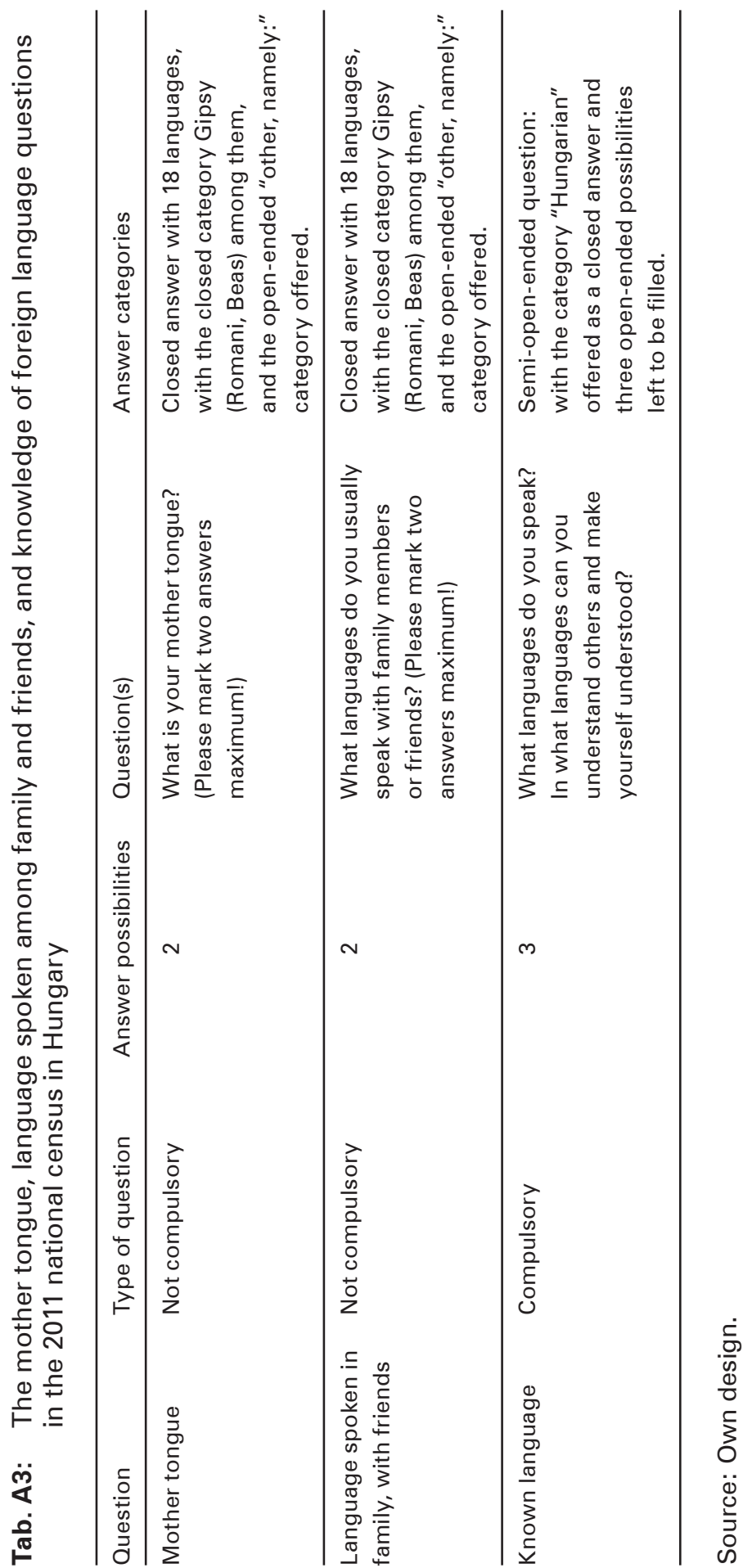


Tab. A4: The average number of children ever born, by women's birth cohort and selected countries, 2011

\begin{tabular}{lcccc}
\hline Birth cohort & Hungary & Romania & Slovakia & Serbia \\
\hline $1952-1956$ & 1.91 & 1.99 & 2.29 & 1.83 \\
$1957-1961$ & 1.95 & 1.97 & 2.24 & 1.83 \\
$1962-1966$ & 1.93 & 1.86 & 2.14 & 1.80 \\
$1967-1971$ & 1.82 & 1.61 & 2.02 & 1.74 \\
$1972-1976$ & 1.55 & 1.54 & 1.76 & 1.60 \\
$1977-1981$ & 1.09 & 1.28 & 1.30 & 1.26 \\
\hline
\end{tabular}

Source: Own calculation based on 2011 national population censuses from Hungary, Romania, Slovakia and Serbia. Full population data.

Tab. A5: The share of non-respondents to the question on the number of children, by women's age group, nationality and level of education, Slovakia, 2011

\begin{tabular}{ccccc}
\hline $\begin{array}{l}\text { Nationality, } \\
\text { Age group }\end{array}$ & $\begin{array}{c}\text { Primary } \\
\text { or below }\end{array}$ & $\begin{array}{c}\text { Secondary } \\
\text { vocational }\end{array}$ & $\begin{array}{c}\text { Secondary, } \\
\text { high school/ } \\
\text { grammar school }\end{array}$ & $\begin{array}{c}\text { Higher } \\
\text { education }\end{array}$ \\
\hline $\begin{array}{c}\text { Slovak } \\
30-34\end{array}$ & 6 & 5 & 6 & 6 \\
$35-39$ & 4 & 3 & 4 & 5 \\
$40-44$ & 7 & 5 & 4 & 5 \\
$45-49$ & 7 & 5 & 4 & 5 \\
$50-54$ & 6 & 6 & 4 & 6 \\
$55-59$ & 6 & 7 & 4 & 7 \\
Roma & & & & 24 \\
$30-34$ & 8 & 9 & 22 & 44 \\
$35-39$ & 5 & 14 & 11 & 52 \\
$40-44$ & 12 & 18 & 42 & 36 \\
$45-49$ & 13 & 25 & 44 & 38 \\
$50-54$ & 14 & 32 & 36 & \\
$55-59$ & 13 & & 19 & \\
\hline
\end{tabular}

Source: Own calculation based on the 2011 Population and housing census, Slovakia, full population data. 
Tab. A6: Average number of children ever born by women's birth cohort, level of Roma nationality and completed education, Hungary, 2011

\begin{tabular}{|c|c|c|c|c|c|}
\hline $\begin{array}{l}\text { Birth cohort/ } \\
\text { Education }\end{array}$ & $\begin{array}{c}\text { Roma } \\
\text { primary } \\
\text { nationality }\end{array}$ & $\begin{array}{c}\text { Roma } \\
\text { attached }\end{array}$ & $\begin{array}{l}\text { Birth cohort/ } \\
\text { Education }\end{array}$ & $\begin{array}{c}\text { Roma } \\
\text { primary } \\
\text { nationality }\end{array}$ & $\begin{array}{c}\text { Roma } \\
\text { attached }\end{array}$ \\
\hline 1977-1981 & & & 1962-1966 & & \\
\hline High & 0.68 & 0.85 & High & 1.90 & 1.84 \\
\hline Medium & 1.81 & 1.75 & Medium & 2.32 & 2.24 \\
\hline Low & 3.04 & 2.94 & Low & 3.46 & 3.37 \\
\hline 1972-1976 & & & $1957-1961$ & & \\
\hline High & 1.37 & 1.34 & High & 1.86 & 1.78 \\
\hline Medium & 2.08 & 2.08 & Medium & 2.29 & 2.36 \\
\hline Low & 3.37 & 3.28 & Low & 3.40 & 3.33 \\
\hline 1967-1971 & & & $1952-1956$ & & \\
\hline High & 1.65 & 1.65 & High & 1.78 & 1.84 \\
\hline Medium & 2.22 & 2.23 & Medium & 2.21 & 2.23 \\
\hline Low & 3.49 & 3.40 & Low & 3.43 & 3.40 \\
\hline
\end{tabular}

Notes: Roma attached are those who answered "Roma" (or beás, oláh cigány, or any other Roma clan name) to the questions on primary nationality, secondary nationality, mother tongue, language spoken with friends and family, and known language.

Source: Own calculation based on the 2011 Population and housing census, Hungary, full population data. 


\section{Comparative Population Studies}

WWW.comparativepopulationstudies.de

ISSN: 1869-8980 (Print) - 1869-8999 (Internet)

\section{Published by}

Prof. Dr. Norbert F. Schneider

Federal Institute for Population Research D-65180 Wiesbaden / Germany

\section{(c) BY-SA}

2021

\section{Managing Editor}

Prof. Dr. Johannes Huinink

Dr. Katrin Schiefer

\section{Editorial Assistant}

Beatriz Feiler-Fuchs

Wiebke Hamann

\section{Layout}

Beatriz Feiler-Fuchs

E-mail:cpos@bib.bund.de

\section{Scientific Advisory Board}

Karsten Hank (Cologne)

Michaela Kreyenfeld (Berlin)

Marc Luy (Vienna)

Natalie Nitsche (Rostock)

Zsolt Spéder (Budapest)

Rainer Wehrhahn (Kiel)

\section{Board of Reviewers}

Bruno Arpino (Barcelona)

Kieron Barclay (Rostock)

Laura Bernardi (Lausanne)

Gabriele Doblhammer (Rostock)

Anette Eva Fasang (Berlin)

Michael Feldhaus (Oldenburg)

Tomas Frejka (Sanibel)

Alexia Fürnkranz-Prskawetz (Vienna)

Birgit Glorius (Chemnitz)

Fanny Janssen (Groningen)

Frank Kalter (Mannheim)

Stefanie Kley (Hamburg)

Bernhard Köppen (Koblenz)

Anne-Kristin Kuhnt (Duisburg)

Hill Kulu (St Andrews)

Nadja Milewski (Wiesbaden)

Roland Rau (Rostock)

Thorsten Schneider (Leipzig)

Tomas Sobotka (Vienna)

Jeroen J. A. Spijker (Barcelona)

Heike Trappe (Rostock)

Helga de Valk (The Hague)

Sergi Vidal (Barcelona)

Michael Wagner (Cologne) 